\title{
Sürdürülebilirliğin Temel Taşı: Ekolojik Ayak İzi
}

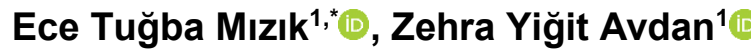 \\ ${ }^{1}$ Eskişehir Teknik Üniversitesi, Mühendislik Fakültesi, Çevre Mühendisliği Bölümü, 26000, Eskişehir.
}

\section{Özet}

Insan nüfusunun artması ve teknolojinin gelişmesiyle birlikte doğal kaynaklara olan talep her geçen gün artmaktadır. Üretim ve tüketim ihtiyaçlarını sağlamak için kullanılan doğal kaynaklar insanların dünyanın sahibi olduğuna dair düşüncelerinden dolayı tahrip edilerek düşüncesizce kullanılmaktadır. Ekolojik ayak izi ifadesi kaynak kullanımının sürdürülebilir bir biçimde gerçekleştirilebilmesi için kullanılan sayısal bir metottur. Bu metot ekolojik kaynakların ekonomik değerlerinin olduğunu belirten ekolojik ekonomi ve sürdürülebilirlik kavramlarının bir bütününü temsil etmektedir. Ekolojik ayak izi kavramı, tüketilen ekolojik verimli kaynak miktarların ve bu kaynakların alan bazında belirlenmesini sağlayarak ekolojik kaynak tüketimini sayısallaştırmaktadır. Son zamanlarda sürdürülebilirlik kavramının disiplinler arası değerlendirilmesi sonucunda ekolojik ayak izi kavramı genişletilerek ayak izi ailesi kavramı oluşturulmuştur. Ayak izi ailesi, ekolojik kaynakların tüketiminin kaynak bazında değerlendirilmesini sağlayarak her bir kaynağın sürdürülebilirliğini sağlamaktadır. Bu çalışmada, ekolojik kaynakların sürdürülebilir yönetiminde anahtar rol oynayan ekolojik ayak izi kavramının tarihçesi ve kaynakların yönetiminde etkin olan ayak izi ailesi hakkında detaylı bir derleme çalışması yapılmıştır.

Anahtar Sözcükler

Ekolojik Ayak İzi, Sürdürülebilirlik, Çevre, Ekolojik Ekonomi

\section{The Cornerstone of Sustainability: Ecological Footprint}

\begin{abstract}
With the increase of human population and the development of technology, the demand for Natural Resources is increasing day by day. The natural resources used to supply the needs of production and consumption are destroyed and used thoughtlessly because of people's belief that they own the world. The term of ecological footprint is a numerical method used for sustainable usage of resources. Ecological footprint expression is a numerical method for sustainable use of resources. This method represents whole of the concepts of ecological economy and sustainability which that present ecological resources have economic value. This method represents a whole of the concepts of Ecological Economics and sustainability, which indicate that ecological resources have economic values. The concept of ecological footprint digitizes ecological resource consumption by ensuring that the amounts of ecologically efficient resources consumed and those resources are determined on a field basis. Recently, as a result of the interdisciplinary evaluation of the concept of sustainability, the concept of ecological footprint has been expanded and the concept of footprint family has been created. The footprint family provides the sustainability of each resource by ensuring that the consumption of ecological resources is assessed on a resource-by-resource basis. In this study, a detailed review of the history of the ecological footprint concept, which plays a key role in the sustainable management of ecological resources, and the footprint family that is effective in the management of resources, has been conducted.
\end{abstract}

$\underline{\text { Keywords }}$

Ecological Footprint, Sustainability, Environment, Ecological Economy

\section{Giriş}

Dünya, içerisinde pek çok ekosistemi barındıran bir bütündür ve bu bütündeki her bir canlı, yaşamını devam ettirmek amacıyla doğal kaynakları kullanmaktadır. Fakat insanoğlunun artan popülasyonu ve gelişme isteğinin artması ile ortaya çıkan ekonomik aktivitelerden dolayı doğal kaynaklar, daha çok tüketilmekte hatta harap edilmektedir. Artan tüketim sonucunda oluşan çevresel etkiler, doğanın bir ‘taşıma/özümseme kapasitesi' ve 'kaynak kapasitesi' olduğunu akıllara getirmiştir. Dünyanın doğal kaynak üretim miktarı ve insanların bu kaynakları tüketmeleri ve tüketim sonrasında oluşan atıkların doğa tarafından tolere edilmesi için gereken ekolojik değer arasındaki fark ekolojik açıklıkları vermektedir. Ayrıca ekolojik açıklıklar, doğa üzerine yapılan baskıları da ifade etmektedir. Günümüzde yapılan çalışmalarda gelişen teknoloji ve ekonomiyle birlikte oluşan çevre kirlilikleri ve aşırı tüketimden kaynaklı dünya üzerinde oluşan bu baskı gün geçtikçe artmaktadır. Dünyada şu anda insan faaliyetlerini desteklemek için 1.7 gezegen eşdeğeri kullanılmaktadır. 
Bu durum günümüzün tüketim seviyelerinde sürdürülemez bir orandır (San-Francisco vd. 2020). Dünya üzerine yapılan baskının en büyük sebeplerinden biri ekonomik adaletsizliktir. Bu adaletsizliğe en güzel örnek dünyanın kuzeyi ve güneyi arasındaki ekonomik farklılıktır. Kuzeydeki ülkeler dünyanın ekolojik ve ekonomik kaynaklarını yönetirken, güneyde bulunan Üçüncü Dünya ülkeleri ise sadece bu sistemin kirlilik baskılarına maruz kalmaktadır.Yoksulluk, çevresel kirlilikler ve dünyadaki yetersiz kaynaklardan meydana gelen sorunların 1992'de Rio de Janerio'da gerçekleştirilen "Çevre ve Kalkınma Konferansı" sonucunda azaltılması gerekliliğini ve ülkelerin dünya üzerinde oluşturdukları bu baskıların azaltılması amacıyla çalışmaların yapılmasının gerekliliğini gözler önüne sermiştir. İnsanların yaşadıkları dünyanın kaynaklarını yaşamlarını devam ettirecek düzeyde kullanıp gelecek nesiller içinde bu kaynakların devamlılığını sağlaması olarak kabul edilen "sürdürülebilirlik" düşüncesi bu konferansla daha çok gündeme gelmiştir. Sürdürülebilir yaşam, Birleşmiş Milletler (BM) Brundtland Komisyonu (WCED 1987) tarafından öngörülen ve 1992 yılında 100'den fazla devlet başkanının Rio'daki Dünya Zirvesi'nde onayladığı konu olmuştur. Sürdürülebilirliğin sağlanması ve toplumun doğa üzerinde oluşturduğu baskıyı hesaplamak amacıyla çeşitli muhasebe araçları oluşturulmuş ve kullanılmıştır. $\mathrm{Bu}$ muhasebe araçlarından bir tanesi de Ekolojik Ayak İzi kavramıdır (Wackernagel vd. 1999).

Ekolojik ayak izi kavramı dünyadaki canlıların kaynakları kullanma ve tahrip etme miktarını nicel değerlere çeviren bir muhasebe aracı olduğundan, insanların dünya üzerindeki tüm canlılara karşı oluşturduğu baskıyı ve üstünlük kurma çabasını gözler önüne sermektedir. Fakat, bir bütün halinde bakıldığında her bir canlı birbirlerinden farklı da olsa dünya adlı bir ekosistem içerisinde yaşamakta ve aynı haklara sahip olmaktadır. Fred Spier'in "Her birimizin, evrenin herhangi bir yerinde oldukça istisnai bir gezegende ortaya çıkan tek, oldukça istisnai bir hayvan türüne ait olduğu fikri; en yakın kuzenlerimizin primatlar olduğunu; aslında, tüm yaşam formlarılla ilgili olduğumuz ve kozmik bir perspektiften bakıldığında, uzak kuzenlerimiz kayalar, su ve hatta yıldızlar olduğudur” düşüncesinden anlaşılacağı üzere bizi oluşturan ve bizi biz yapan doğaya bağlılığımız hiçbir zaman kopmayacaktır (Penna 2010). Bu bağımlılığı daha çok anlamamız ve kavramamızı sağlayan ekolojik ayak iziyle daha iyi sürdürülebilir bir gelecek oluşturabilecektir. Bu çalışmanın amacı; çevre ve sürdürülebilirlik kavramlarının irdelenmesi, çevre ve ekonomi arasındaki ilişkinin nassıl başladığının açıklanması, ekoloji ve çevre perspektifiyle oluşturulan ekolojik ekonominin bir alt dalı olan ekolojik ayak izinin tarihsel gelişimi ve dalları ile ilgili detaylı bir derleme çalışmasının Science Direct ve Google Scholar kullanılarak yapılmasıdır.

\section{1. Çevre ve Sürdürülebilirlik}

18. yüzyılda buhar makinelerinin icadıyla başlayan Sanayi Devrimi çevresel sorunların gündeme gelmesinde bir başlangıç noktası olmuştur. Ana öncül, üstel büyüme ve ekonominin globalleşmesiyle devam eden, insanlığın çevreyle ilişkilerinin doğası, son birkaç on yılda dramatik ve geri dönüşümsüz bir şekilde değişmiştir. İkinci Dünya savaşından bu yana dünyanın ekonomik aktivitesi dört ila beş kat artmış, ekosfer ve insan ekonomik alt sistemi arasında eşi benzeri görülmemiş düzeyde madde ve enerji değişimi sağlanmıştır (Rees 1995). Ekolojist hareketin mimarı olan Rachel Carson, 1962'de Sessiz Bahar'1 yayınlayarak (Carson 1962), böcek ilacı olarak DDT'nin (Dikloro Difenil Trikloroetan) yaygın olarak uygulanmasıyla ilgili riskleri tartışarak DDT'nin faydadan çok zarara neden olduğunu ve çevre ve insan sağlığı üzerindeki olumsuz etkilerin hala büyük ölçüde bilinmediğini tartışmıştır (Rojas-Fernández vd. 2017).

Sessiz Bahar kitabıyla birlikte insanların dünya üzerinde kendi çıkarları için doğada bulunmayan çeşitli kimyasalların üretilmesinin dünya üzerinde yıkıcı etkiler oluşturacağına dikkat çekilmiştir. Ekonomik büyüme ve savaşların bir sonucu olan nüfus artışıyla birlikte dünyanın kaynak ve taşıma kapasitesinde yavaş yavaş meydana gelen dengesizliklerin ortaya çıkması pek çok bilim insanı tarafından fark edilmeye başlanmıştır. 1968'de biyolog Paul Ehrlich'in yayınladığı Nüfus Bombası (The Population Bomb) adlı kitap, 1960'larda çevresel konuların farkındalığını arttıran diğer etkili bir yayın olmuştur. Ehrlich bu kitapta insan popülasyonlarındaki artışın azalmadan devam etmesiyle doğa üzerinde oluşacak yıkıcı etkileri sade bir dille anlatııştır.

Artan nüfus ve buna bağlı artan enerji talebiyle birlikte ülkeler farklı enerji kaynakları bulmaya yönelmiştir. Bu amaçla her ülke enerji kaynaklarını sağlamak amacıyla çeşitli ülkelerden petrol ve doğalgaz gibi kaynakları satın almaya başlamıştır. Fakat Orta Doğu'da meydana gelen çatışmalardan dolayı talep edilen enerji kaynakları alınamamış ve bunun sonucunda bir enerji krizi ortaya çıkmıştır. Enerji kriziyle birlikte, İngiliz Ekonomist E. F. Schumacher "Küçük Güzeldir: Önceliği İnsana Veren Bir Ekonomi Anlayışı (Small Is Beautiful: Economics as if People Mattered)" kitabını yayınlamıştır. Kitap, 1973 yılında yazılmış ve daimî ekonomik büyümenin sürdürülebilir olmadığı fikrini en erken dile getiren bir yayın olmuştur.

Yukarıdaki kitapların 1şı̆̆ında çevre sorunlarının kirlilik kaynağı üretimi, popülasyon artışı ve bu ikisinin birleşimiyle ifade edilen ekonomik büyüme kaynaklı tüketim artışıyla birlikte ülkeler çeşitli çalışmalar yapmıştır. 1960 ve 1970'i takip eden yıllarda çevreyle ilgili bakanlıklar açılmış, yeni yasalar oluşturulmuş ve bu konu hakkında daha yoğun çalışmalar gerçekleştirilmiştir. 1970 yılında Amerika Ulusal Çevre Politikası Yasası (NEPA) Başkan Nixon tarafından imzalanmıştır. 1970 yılında Amerika'da kurulan NEPA pek çok bilim insanı tarafından çevrenin Magna Carta'sı olarak adlandırılmıştır. Bunun nedeni dünyada hükümdarlığını sürdüren insanlığın, çevre üzerinde bir üstünlüğünün olmadığını ve her canlının doğa karşısında eşit olduğunu akıllara getirmesidir. 
NEPA, Kongre'nin çıkardığı çevre yasalarını uygulamakla mükellef bir devlet organı federal ajansı olan Çevre Koruma Ajansı'nın (EPA) kurulmasını sağlamıştır (Robertson 2014). Roma Kulübü, farklı disiplinlerdeki bilim insanlarından oluşan ve doğaya uygulanan baskıların gelecekte oluşturacağı etkileri ortaya koyan bir organizasyondur. Roma Kulübü, oluşan bu baskıları ortaya çıkarmak amacıyla 1961'de kurulan Massachusetts Institute of Technology'deki (MIT) bilim insanlarının geliştirdiği simülasyon hesaplamalarıyla gelecek senaryoları oluşturmak amacıyla bir çalışma gerçekleştirmiştir. MIT teknisyenleri tarafından yapılmış bilgisayar simülasyonlarının sonuçları, yenilenemeyen kaynakların tüketilmesi ve sonuçta oluşan ürün değerlerinin artmasına dikkati çeken Büyümenin Limitleri (Meadows vd. 1972) yayınlanmıştır (Paul 2008). Şekil 1'de Büyümenin Limitleri raporunda söz edilen gıda ve yenilenemeyen kaynakların düşüncesizce tüketiminin azaltılarak sürdürülebilir geleceğin sağlanması için gerekli olan temel koşullar gösterilmiştir.

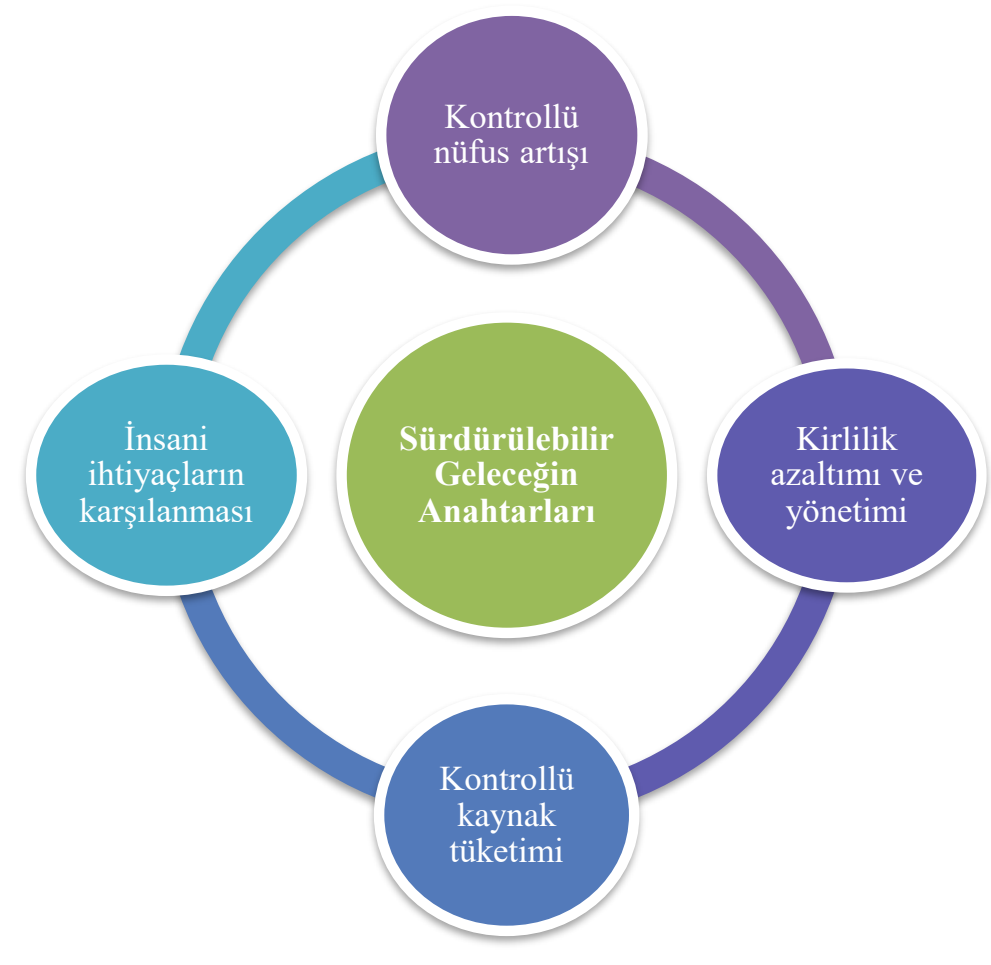

Şekil 1: Büyümenin Limitleri raporunun temel sonuçları (Meadows vd. 1972)

$\mathrm{Bu}$ rapor 1şı̆̆ında ekosistem üzerine yapılan baskıların azaltılması ve gelecek nesillerin de yaşamlarını sürdürebileceği bir dünyanın zemininin hazırlanması için çalışmalar daha da hızlanmıştır. 1972'de İsveç'te çevre ve insan arasındaki ilişkinin daha çok gündeme gelmesini sağlayan 113 devletin ve 19 uluslararası organizasyondan katılımcının katılımıyla çevresel konulara bağlı ilk uluslararası Birleşmiş Milletler Çevre ve İnsan Konferansı (Stockholm Konferansı) gerçekleştirilmiştir. Stockholm konferansı sonrasında çevresel sorunları ve ekonomik sorunları bir araya getirecek bir yapı oluşturmak amacıyla çeşitli çalışmalar gerçekleştirilmeye başlamıştır. Gerçekleştirilen çalışmalar sonucunda farklı birimler meydana getirilmiş ve çeşitli çalışmalar gerçekleştirilmiştir.

Stockholm Konferansı'nın bir diğer sonucu ulusların ve toplumların gelecek nesilleri riske atmadan yaşam kalitelerini yükseltmelerine teşvik ederek, çevreye özen göstermede ilham veren, ortaklık ilişkilerini teşvik eden ve liderlik ihtiyacını karşılayan bir Birleşmiş Milletler Çevre Programı'nın (UNEP) oluşturulmasıdır (Paul 2008). Birleşmiş Milletler Çevre Programı'nın (UNEP) kurulmasıyla birlikte gelecek nesillere doğal kaynak ve ekonomik bir değer bırakma düşüncesi yavaş yavaş sürdürülebilirlik olgusunun temellerini atmıştır. 1983 yılında Birleşmiş Milletler Dünya Çevre ve Kalkınma Komisyonu (WCED), 20 ülkenin katılımıyla dönemin Norveç Başbakanı Gro Harlem Brundtland yönetiminde Ortak Geleceğimiz (Brundtland) raporunu hazırlamıştır ve 1987 yılında Birleşmiş Milletler genel kurulunda sunulmuştur. Komisyon, sürdürülebilir kalkınmayı "gelecek nesillerin kendi ihtiyaçlarını karşılayabilme yeteneğinden ödün vermeden bugünün ihtiyaçlarını karşılayan” olarak tanımlamıştır. Bu tanım, gezegendeki tüm insanlar için yaşamları ödüllendirme amacının, ekosistemlerin, toplumun gelişmesi için gerekli olan kaynakları ve atık emilim hizmetlerini sürekli olarak sağlayabilmesi gerektirdiğini kabul etmiştir (Atlas 2010). Ortak geleceğimiz raporu sonucunda gündeme gelen ve temelleri atılan sürdürülebilirlik kavramının doğuşu ve tarihsel gelişiminde etkin olan çalışmalar Şekil 2'de gösterilmektedir. 


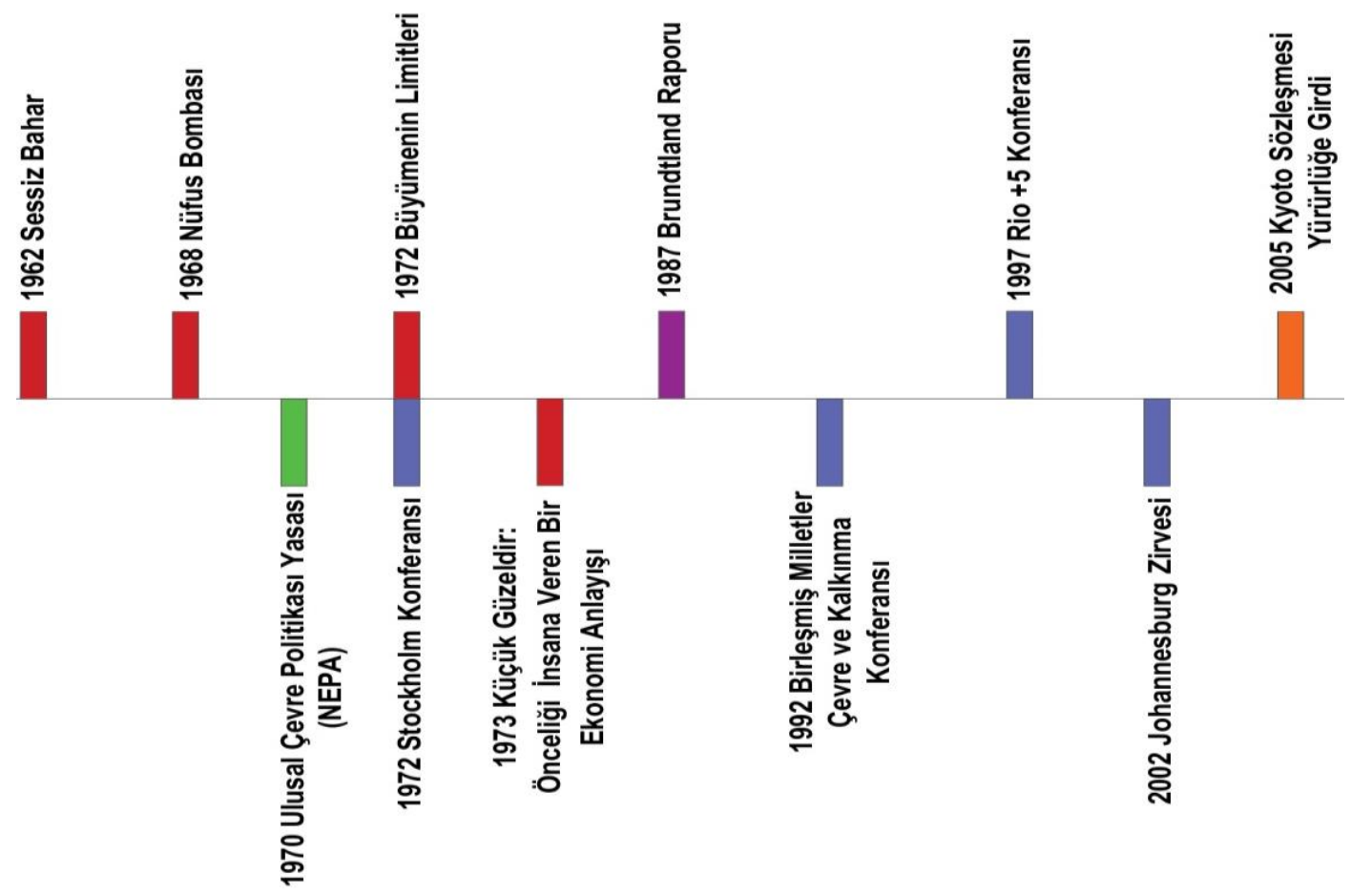

Şekil 2: Sürdürülebilirlik kavramının doğuşu ve tarihsel gelişiminde etkin olan çalışmalar

Brundtland raporu sürdürebilirlik düşüncesinin ilk tohumlarını atmıştır. Sürdürülebilir yaşam Birleşmiş Milletler Brundtland Komisyonu (WCED 1987) tarafından öngörülen ve 1992 y1lında 100'den fazla devlet başkanının Rio'daki Dünya Zirvesi'nde kabul ettiği bir kavram olmuştur (Wackernagel vd. 1999). Sürdürülebilirliğin ilk tanımı resmi olarak Rio'daki BM Çevre ve Kalkınma Konferansı'nda (UNCED) yapılmıştır. Konferansta insanların dünya üzerinde bir hakimiyetinin olmadığı ve her insanın nerede yaşıyor olursa olsun aynı temel haklara sahip olduğu vurgulanmıştır. Gündem 21, UNCED'de ortaya çıkmış ve yerel düzeyde gelişim için çağrıda bulunmuştur. Gündem 21, UNCED'den etkin bir şekilde faydalanılmasını sağlamak, uluslararası işbirliğini arttırmak, ve Gündem 21 uygulamasının yerel, ulusal, bölgesel ve uluslararası seviyelerde gelişiminin arttırılması için Birleşmiş Milletler Sürdürülebilir Kalkınma Komisyonu'nun kurulmasını istemiştir (Koroneos ve Rokos 2012). Ayrıca bu konferansta sunulan Gündem 21, sürdürülebilirliğin sadece insanlarla sınırlı kalmaması sürdürülebilir orman, sürdürülebilir tarım, kırsal kalkınmanın teşvik edilmesi konularının da üzerinde durmuştur. 1992 yılında Rio'da gerçekleştirilen BM Çevre ve Kalkınma Konferansı (UNCED) sonrasında alınan kararların gerçekleştirilip gerçekleştirilmediğinin belirlenmesi ve yeni kararlar alınması amacıyla 5 yıl sonra tekrar Rio+5 adlı özel bir oturum gerçekleştirilmiştir. Çevre ve sürdürülebilirlik ifadesinin yanı sıra Birleşmiş Milletler Çevre ve Kalkınma Konferansı ile gündeme gelen iklim değişikliği ifadesiyle Rio Sözleşmeleri'nden biri olan Birleşmiş Milletler İklim Değişikliği Çerçeve Sözleşmesi (BMÇiDÇS) 1994 y1lında kabul edilmiştir. Bu sözleşmenin kabulü sonrasında 11 Aralık 1997'de Kyoto'da pek çok ülkenin katılımıyla geçekleştirilen 3. Taraflar Konferansı'nda (COP3) iklim değişikliğine neden olan sera gazlarının azaltılması amacıyla çeşitli hükümler belirlenmiştir. 2002 yılında Johannesburg'da gerçekleştirilen Dünya Sürdürülebilir Kalkınma Zirvesi'nde, sürdürebilirlik kavramı yeniden ilgi ve tartışma odağı olmuştur. Johannesburg Zirve’sinin ‘insan, dünya, refah' sloganı, çevre korumasının ekonomik ve sosyal gelişimin dengesi anlamına gelen sürdürülebilir gelişimin gerekliliğini yansitarak benimsetmiştir (Hammond 2006).

1997'de gerçekleştirilen COP3'te ortaya konan Kyoto Protokolü ülkelerin çıkar uyuşmazlıkları nedeniyle 2005'in Şubat ayında yürürlüğe geçebilmiştir. Ancak Kyoto Protokolü 2012 yılına kadar geçerli olduğundan 2007 yılında gerçekleştirilen 13. Taraflar Konferansı'nda (COP13) Bali Yol Haritası'nın kabul edilerek müzakerelerin iki hat üzerinden ilerlenmesi sağlanılmıştır. COP13 sonrasında 2009 yılında gerçekleştirilen Kopenhag Mutabakatı'nda (COP15) Dünya sıcaklığının ikiden fazla artmaması için yapılması gerekenlere değinilmiştir. Ancak bu anlaşmanın taslağı gerçekleştirilecek bir sonraki toplantılara bırakılmıştır. Bunun dişında 2010 yılında Cancun, Meksika'da COP16, 2011 yılında Durban, Güney Afrika'da COP17, 2012 yılında Doha Katar'da COP18, 2013 yılında Varşova Polonya'da COP19 ve 2014 yılında Lima Peru'da COP20 gerçekleştirilmiştir (Kıvılcım 2013). COP20 zirvesi sonrasında 2015 yılında Paris’te COP21 gerçekleştirilmiştir. Bu zirvede 2020 sonrasındaki küresel iklim rejiminin esaslarını ifade eden Paris Anlaşması'nın imzalanması gündeme gelmiştir. Bu anlaşma yeterli sayıda ülkenin parlamentosunca onaylanarak 2016 Kasım'da yürürlüğe girmiştir (Parıltı 2019). COP20 sonrasında gerçekleştirilen COP21 ve COP22'de Paris Anlaşması'ndaki eksiklikler değerlendirilmiş ve tartışılmıştır. Eksikliklerin minimum düzeye indirilmesi sonrasında 2018 yılında Katoviçe'de gerçekleştirilen COP23 zirvesi ile Paris Anlaşması'nın maddelerinin uygulanabilirliğini arttırmak amacıyla "Paris Kural Kitabı" yayınlanmıştır. 


\section{2. Çevre ve Ekonomi Arasındaki İlişkinin Doğuşu}

Çevre ve ekonomi birbirlerinden ayrı iki bilim dalı olmasına rağmen ekolojik kaynakların tüketimden dolayı bir değere sahip olması düşüncesi bu iki bilim dalını bir araya getirmiş̧tir. Çevre ve ekonominin bağdaştırılma süreci, Roma Kulübü'nün 1972'de yayınlanan Büyümenin Limitleri adlı yayınında insan nüfusunun artması sonucunda kaynakların adaletsiz dağılımıyla meydana gelen ekonomik adaletsizliğin çevresel baskılar oluşturduğu fikriyle başlamıştır. Raporun sonuçları 1şı̆̆ı̆ında adaletli bir kaynak dağılımının sağlanabilmesi için her bir ekolojik kaynağın bir ekonomik değerinin oluşturulması gereklidir. Oluşturulan bu nitel değer ülkeler arasındaki adaletsizliği daha net görmemize ve sürdürülebilir bir geleceğin zeminlerinin hazırlanmasına katkı sağlayacaktır.

Ekoloji ve ekonomi kavramların incelediğimizde temel farklılıklar ve bu farklılıklar sonucu oluşan ekolojik ekonomi kavramının bir noktada birleşme sürecini daha da yakından görebilmekteyiz. Ekoloji, enerji akışlarını ve ekolojilerin vasıtasıyla madde kaynaklarını ve farklı türler arasındaki kaynakların paylaştırılması için evrimleşmiş rekabet ve birlikte yaşam mekanizmalarının bilimsel çalışmasıdır. Ekoloji, gerçek dünyanın kimyasal ve termodinamik kanunlarında sağlam köklere sahiptir, tüm enerjinin ve organik dünyanın madde transferlerinin evrensel düzenleyicileridir. Ekonomiler on dokuzuncu yüzyılın sonunda klasik organik köklerini terk etmiștir. Neoklasik ekonomi Newton'un analitik mekanizmalar kavramını ve metotlarını sağlam bir şekilde baz almaktadır (Rees 1992). Bunun yanında ekolojiyle ekonominin kavramsal farklılıkları pek çok ikilemi bir araya getirmiştir. Ekonominin kökenlerinin sabit olması ve değişime açık olamaması ekonomiyi ekolojik faktörlerden yoksun ve değerlendirilemez bir durumun içine çekmiştir. Ancak doğal kaynakların kullanımıla oluşturulan üretim sistemleri ekolojik kaynaklara bağımlıdır. Bu durum ekonomik değeri olan bütün maddelerin, bir ekolojik değeri olduğunu gözler önüne sermektedir. Ekolojik kaynakların tükenmeyeceğini tükenme fikrinin sadece ekolojiye bir değer verilmesinden kaynaklı oluştuğunu iddia eden Neoklasik ekonominin aksine, ekonomistler dünyadaki kaynak tüketimini göz önüne seren entropik değişimi baz alan termodinamik kanunlarına yoğunlaşmıştır. Ekolojik kaynakların ekonomik bir değer ile bağdaştırılmasını sağlayan termodinamik kanunlarına bağlı ekonomi düşüncesi Şekil 3'de ifade edildiği gibi klasik ekonomik düşünce yapısı ile ekolojik kaynak tüketiminin birleşmesi ile ortaya çıkmışıı.

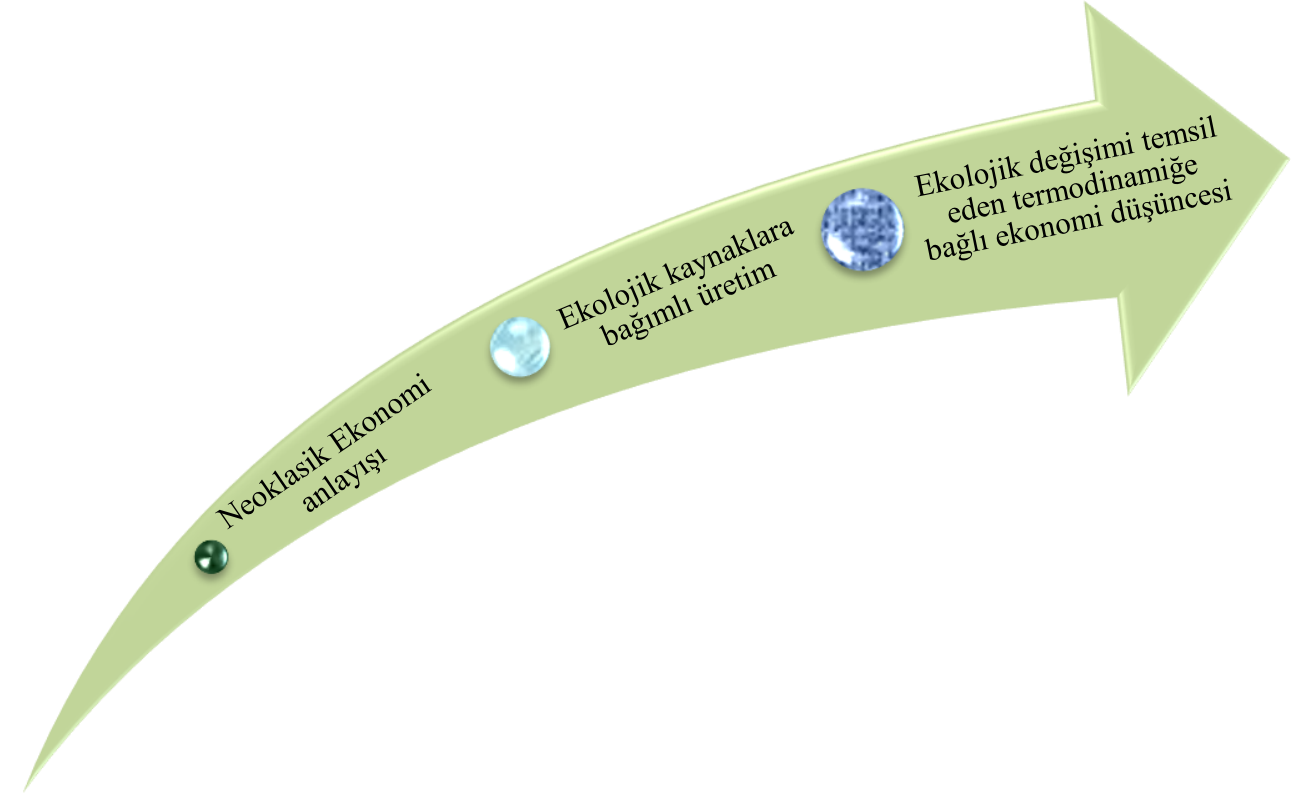

Şekil 3: Ekoloji ve ekonominin kesişimi olan termodinamiğe bağlı ekonomi düşüncesi

Termodinamikten ilham alan, sistem ekolojistleri ekosistemlerdeki enerji ve madde akışları kavramlarını betimleyen yeni çalışma perspektifleri geliştirdiler ve bir grup ekolojist bu analiz vasıtasıyla ekosistemlerin insan aktiviteleriyle daha çok bütünleştiğinin farkına varmıştır. Ayrıca insan aktiviteleri, madde ve enerji akışları kavramlarıyla tanımlanabilmektedir ancak bazı sistem ekolojistleri ekonomik konulara daha çok odaklanmaktadır (Røpke 2005). Bu tartışmalar sonucunda ekolojistler, ekonominin meydana getirdiği çevresel baskı ile ekolojik kaynaklara olan bağımlığ1 gözler önüne sermişlerdir. Bu doğrultuda ekonomi ve doğa arasındaki ilişkiyi tanımlamaktansa temelde iki farklı sistemi bağdaştırmayı ifade etmişlerdir. Ekonomistler, insan ekonomisinin doğada saklı olduğunun üzerinde durarak ve ekonomik süreçleri, biyolojik, kimyasal ve fiziksel prosesler olarak gördüğünden doğal süreçler bakımından kavramsallaştırmışlardır (Røpke 2005). Böylece klasik hesaplamalardan ibaret ve değişmez kalıpları olan bir ekonomi yerine ekolojik değerleri de içinde barındıran yeni bir ekonomi kavramı oluşturulmuştur.

Taşıma kapasitesi, genellikle belli bir türün maksimum popülasyonun habitatının verimliliğini kalıcı olarak bozmaksızın belli bir habitatı süresiz olarak destekleyebilirliği olarak tanımlanmaktadır (Rees ve Wackernagel 1996). 
Fakat insanlar yaşadığı gezegenin taşıma kapasitesini göz ardı edilmeksizin kıt kaynakları tüketmekte, rekabet gücü yüksek canlıları ortadan kaldırarak ekolojik dengeyi bozmakta ve teknolojiyle birlikte ekonomik değeri arttırmak amacıyla doğayı sömürmektedir. Herman Daly’nin eleştirel bir biçimde gözlemlediği gibi, egemen vizyon ekonomisi çevresel kısıtlamalardan serbest hareket eden bir dünya varsaymaktır (Rees ve Wackernagel 1996). Taşıma kapasitesi, doğadan kaynak sağlanması ve ekonomik yarar kavramlarının meydana getirdiği ekolojik ekonomi kavramı Şekil 4'de şematize edilmiştir. Ekolojik ekonomi kavramı, ekonominin ekolojiye olan bağlılığını ve doğal değerlerin sadece doğaya ait olmadığını bu yüzden her bir doğal varlığın ekonomik bir değer içermesi gerektiğini savunmaktadır. Yani ekolojik ve ekonomik sistemler aynı enerji ve madde akışı diliyle bağdaştırıldığında insan ekonomisinin yeryüzü biojeosferinde gömülü olduğu açıkça belirtilmektedir.

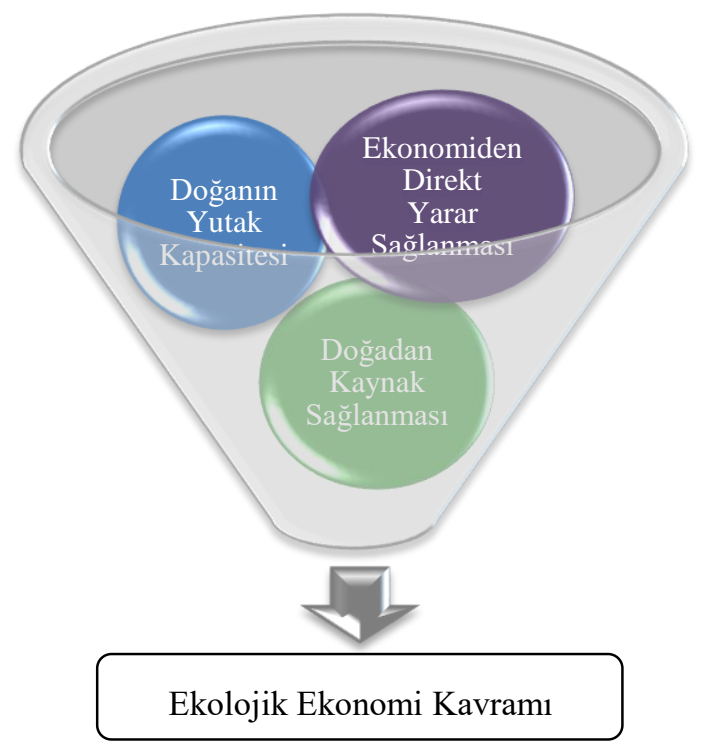

\section{Şekil 4: Ekolojik ekonomi kavramının temel bileşenleri}

Dünya çevresindeki evrenle tam anlamıyla bir enerji alışverişi içerisinde değilken, kendi içerisinde sürekliliği olan bir madde döngüsüne sahiptir. Bu madde döngüsü içerisinde ekonomik baskılar nedeniyle oluşan değişimler doğa üzerindeki koşulların değişmesine ve çevre sorunlarının oluşmasına neden olacaktır ve olmaya devam edecektir. Ekolojik ekonominin düşünce yapısı insan toplumları için temel yaşam desteği sağlayan ve iyi işleyen ekosistemlere olan insan bağımlılığının anlaşılacağı bir farkındalık sağlamaktadır. Bir başka değişle, birçok biyofiziksel sermaye teknolojinin yerini alamayacağı kritik fonksiyonları yerine getirmektedir. Sürdürülebilirlik için, bu tür sermayelerin kritik minimal bir miktarı bozulmadan ve yerinde korunmuş olması gereklidir.

$\mathrm{Bu}$ insanların bağlı olduğu ekosistemler üzerinden kendi kendini organize etmesi ve üretimlerini yapabilmesinin sürekliliğini sağlamaktadır (Rees ve Wackernagel 1996). Bu durumda akla gelecek ilk şey doğanın sermaye stoklarının şu anki insan popülasyonun tükettiği miktar için yeterliliği ve bunun yanı sıra gelecek kuşakların yaşamlarını devam ettirmesi için gerekli olacak miktarı sağlayıp sağlayamayacağıdır. Kısacası dünyanın yeterli bir taşıma kapasitesi var mıdır? Günümüzde, şüphesiz, insan popülasyonu ve ortalama tüketimin her ikisi de artmaktadır, halbuki toplam üretken arazi alanı ve doğal sermaye stokları sabit ya da azalmaktadır (Rees ve Wackernagel 1996). Bu bağlamda, küçülecek taşıma kapasitesi yakın zamanda insanlığın karşı karşıya kalacağı önemli bir konu olacaktır.

Gelecek nesillerin çıkarları dikkate alınmalı, ekonomik skalanın limiti olmalıdır ve onun için, adalet ve dağılım konuları öne çıkmaktadır. Çevresel limitlerden dolayı, dar gelirli, ekonomik büyümenin sürekliliğinden korunamaz, bu yüzden refah seviyesi daha yüksek olan insanlar etik zorluğu gözeterek yeniden dağıtımın artan gerekliliğine odaklı olmalıdır (Røpke 2005). İnsan taşıma kapasitesini, maksimum popülasyon değil de insanların güvenli olarak uyguladığ maksimum yük (entropi) yerine tanımlarsak, konu daha iyi anlaşılacaktır. İnsan yükü açıkça sadece nüfusun değil, kişi başına tüketimin ortalama bir işlevidir (Rees ve Wackernagel 1996). Bu entropik yük gelişen teknoloji ve ekonomiye bağlı olarak tüketim miktarında büyük bir atış gözlemlenmektedir. Entropik yükteki bu artışla doğanın kaynak sağlama kapasitesi arasında bir dengesizlik meydana gelmektedir. Bu muazzam entropi dengesizliği, ekolojik ayak izi analizinin ilk aksiyomu olarak adlandırılabilir. Ülkeler ve bölgeler arası gelişmişlik düzeyi tüketim ve ekosistem üzerine oluşturulan baskının değişim göstermesinde büyük bir rol oynamaktadır. Yirmi birinci yüzyılda kentleşme ve kent yaşamının maddi temelinin temel insan ekolojisi üzerinde ciddi etkileri vardır. Odak noktası olarak doğal sermaye verimliliğine erişim şartları açısından kuzey ve güney arasında belirgin bir fark vardır. Zengin sanayileşmiş ülkelerin 'net gezegen ürününü' büyük oranda orantısız olarak paylaştırması küresel ekonominin biyofiziksel sınırları üzerine baskı oluşturmaktadır. 
Bu baskı böyle devam ederse daha da denge bozucu jeopolitik bir faktör haline gelmesi olasıdır (Rees 1992). Bu doğrultu da küresel ekonominin biyokapasite üzerindeki baskısını ele alacak birçok uygulama ortaya çıkmaktadır. Ülkemizde ekonomik faaliyetlerde çevre kavramı politika yapıcılar ve ekonomik birimlerin öncelikleri arasında yer alamamakta, ekonomik performanslar genel olarak ekonomik girdi ve çıktılar tarafından değerlendirilmektedir (Turan ve Güner 2017). Ancak yüksek biyokapasiteye sahip olan ülkemizdeki ekonomik faaliyetlerin kaynakları tahrip etmesi sonucunda oluşan çevre sorunları ile birlikte ülke gündemine girmiştir. Bu kapsamda ülkemizde çevre vergileri uygulanarak üretim ve tüketim süreçlerinde çevreye verilen zararların önüne geçilmeye çalışılmaktadır. Ancak ülkemizde çevrenin korunması, yönetilmesi ve denetilmesi amacıyla Çevre Temizlik Vergisi dışında bir çevre vergisi bulunmamaktadır (Toprak 2006). Bunun yanı sıra ülkemizin ekonomik, sosyal ve çevresel gelişiminin belirlenmesi için belirli periyotlar ile yayınlanan kalkınma planlarında sürdürülebilir bir ekonominin oluşturulması ifadesine çokça yer verilmektedir. Örneğin, ülkemizin 2023 yılı hedeflerini içeren On Birinci Kalkınma Planı “istikrarlı ve güçlü bir ekonomi, rekabetçi üretim ve verimlilik, nitelikli insan ve güçlü toplum, yaşanabilir şehirler ve sürdürülebilir çevre ile hukuk devleti, demokratikleşme ve iyi yönetişim gelişme (URL-1 2019)” ifadelerini temel almaktadır.

\section{Ekolojik Ayak İzi}

Her ülkenin dünya ekosisteminde bir etkisi vardır, fakat bu etki hemen görülebilecek bir etki değildir, bunun yanında bu etkiler sadece bölgelere bağlı değil küreseldir. Bu yüzden oluşturulan baskıların belirlenmesi ve nicel bir değerle ifade edilmesi gerekmektedir. Ekoloji ve ekonominin birbirinden ayrılamaz iki kavram olduğunu gözler önüne seren ekolojik ekonominin ortaya çıkmasıyla birlikte çeşitli metodolojiler ortaya çıkmıştır. Ekolojik Ayak İzi, bir çok yayılmacı ekonomi modelinden daha iyi gerçeğe yaklaşan biyofiziksel tabanlı, ekolojik ekonomi geliştirmeye yönelik bir girişimdir (Moffatt 2000). Ekolojik ayak izi, doğaya olan bağımlılığımızı ölçer. Ekolojik ayak izi metodu küresel, bölgesel, yerel ve kişisel arz ve talebe dayalı doğal kaynak muhasebesi için bir sistem yaklaşımı sağlar (Wackernagel vd. 1997). Her ulus, sürdürülebilirliği sağlamak için ekolojik kapasiteye bağlıdır. Her ulusun ekolojik baskılar sonucu oluşturdukları ekolojik ayak izleri, yani bu baskıları eliminize etmesi için gereken arazi miktarı farklıdır. Bu farklığın yanı sıra araziler arasındaki alan hesaplama metotları ve birimlerinin farklılı̆̆ büyük bir sorun oluşturarak, karşılaştırma sırasında hatalı değerlendirmelere sebebiyet vermektedir. Ekolojik ayak izi, tanımlanmış bir ekonominin veya popülasyonun biyolojik açıdan verimli alanlara göre kritik doğal sermaye gereksinimlerini temsil etmektedir. Açıkça, Şekil 5'de gösterildiği üzere Ekolojik Ayak İzi’nin alanı nüfus büyüklüğüne, malzeme yaşam standartlarına, kullanılan teknolojiye ve ekolojik üretkenliğe bağlıdır (Wackernagel vd. 1999).

Modern ekolojik ayak izi konsepti, Mathis Wackernagel ve William Rees tarafından 1900'lerin başında ifade edilmiştir. Ekolojik Ayak İzi muhasebesi, biyolojik kaynakların insanlarca tüketimi ve bu tüketimden dolayı oluşturduğu atıkların tolere edilmesi için ekosistemin oluşturduğu biyokapasitenin karşılaştırılması amacıyla tasarlanmıştır. Populasyonların yaşamlarında tükettiği yenilenebilir kaynaklarını, güneş enerjisi kullanarak oluşturulmaktadır. Bir popülasyonun Ekolojik Ayak İzi fotosentetik enerji kullanarak oluşturulan biyokütleye sahip olan alanların kullanımı ve tüketimiyle ifade edilmektedir (Kitzes vd. 2009).

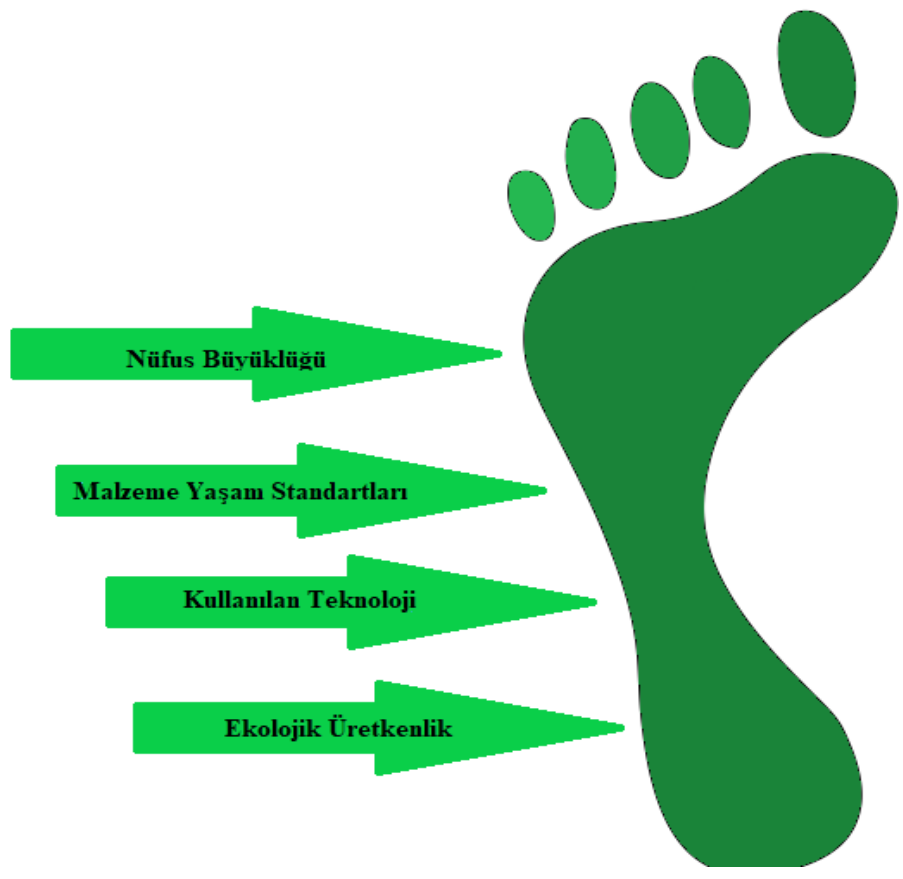

Şekil 5: Ekolojik Ayak Izinin Alanını Değiştiren Parametreler 
Ulusal Ekolojik Ayak İzi’nin küresel boyutta karşılaştırılması için farklı ekosistem türleri altında arazinin potansiyel verimliliğini karşılaştıran ortalama dünya verimi ve eşdeğerlik faktörleri kullanılarak küresel hektar biriminde hesaplanmakta ve raporlanmaktadır. Ekolojik Ayak İzi bu faktörler kullanılmadan yerel hektarla da hesaplanabilir. Bazı bölgelerin karşılaştırılması küresel hektarla yapılan hesaplamalarla zor ve karmaşık olduğundan yerel hektarla oluşturulan hesaplamalarla karşılaştırma yapılmaktadır (Kitzes vd. 2009). Küresel hektar cinsinden hesaplanan biyolojik olarak verimli alanlar, hesaplamada tüketildiği miktarların belirlenmesi ve alansal bazda bir karşılaştırılma yapılabilmesi amacıyla kategorize edilmektedir. Ekolojik olarak üretken olan alanlar Şekil 6'da gösterildiği gibi 6 ana kategoriye ayrılmaktadır (Wackernagel vd. 1997).
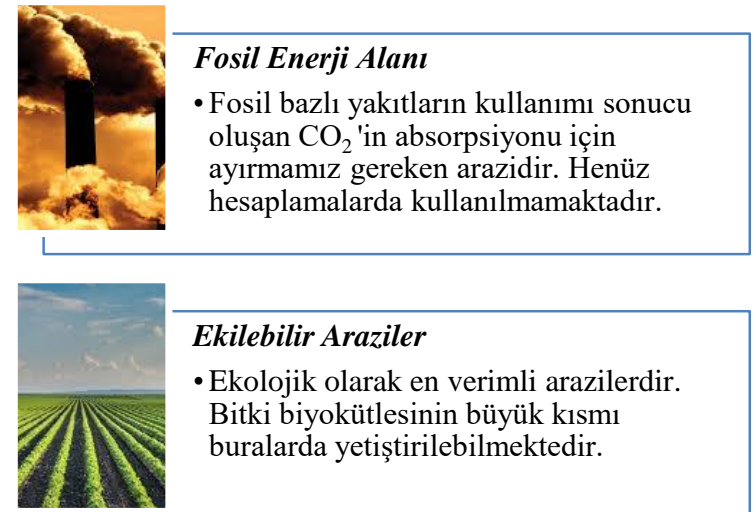

\section{Ekilebilir Araziler}

-Ekolojik olarak en verimli arazilerdir. Bitki biyokütlesinin büyük kısmı buralarda yetiştirilebilmektedir.

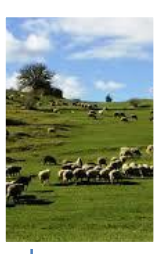

\section{Otlak Alanlart}

- Mandıra ve sığır çiftçiliği için otlak alanlarıdır. Biyokütle biriktirme oranları tarımsal arazilere göre düşüktür. Meraların genişlemesi ormanların küçülmesine neden olmaktadır.

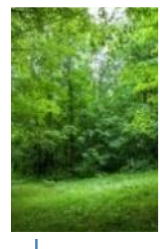

\section{Orman Alanlar}

- Kereste üretim alanları veya doğal ormanları ifade etmektedir. Erozyon, iklim kararlılığı, hidrolojik döngü ve biyoçeşitliliğin korunması için uygun biçimde yönetilmelidirler.
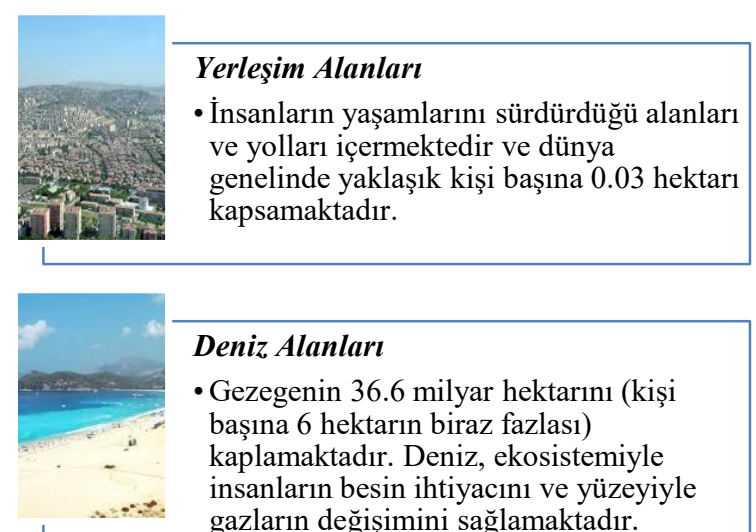

\section{Deniz Alanları}

- Gezegenin 36.6 milyar hektarını (kişi başına 6 hektarın biraz fazlasi) kaplamaktadır. Deniz, ekosistemiyle insanların besin ihtiyacını ve yüzeyiyle gazların değişimini sağlamaktadır.

\section{Şekil 6: Ekolojik olarak üretken alanlar (Wackernagel vd. 1997)}

Yukarıda bahsedilen biyolojik olarak üretken alanların, Şekil 7'de ifade edilen insan tüketimi için kaynak oluşturacak kısmı biyokapasite olarak adlandırılmaktadır ve ekolojik ayak izi gibi küresel hektar (kha) ile ifade edilmektedir. Tüketimin bir ifadesi olan ekolojik ayak izi ile biyokapsitenin karşılaştırılması dünya üzerindeki ekosistem açıklıkları hakkında bilgi vermektedir.

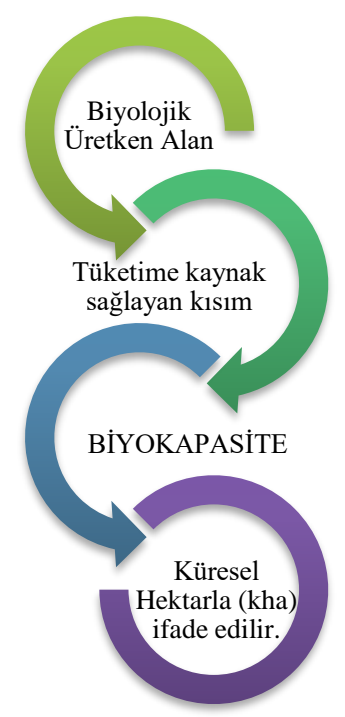

Şekil 7: Biyokapasite 
Ekolojik ayak izi hesaplamaları Şekil 8'de gösterildiği üzere iki basit faktörü baz almaktadır:

1. Tükettiğimiz kaynakların ve ürettiğimiz atıkların takibini gerçekleştirebiliriz;

2. Bu kaynak ve atık akışlarının büyük bölümünü, bu fonksiyonların sağlanması için gerekli olan biyolojik olarak verimli bir alana dönüştürebiliriz (Wackernagel vd. 1999).

Fakat bu dönüştürülen araziler, uluslararası ticaret ve çevresel baskıların küresel olmasından dolayı tek bir kara parçası olarak düşünülmemelidir. Bunun yerine insanların ekolojik hizmetlerini sağladıkları kara ve su alanları olarak kabul edilmelidirler. Basit bir ifadeyle işgal edilen bu alanlar tükettiğimiz tüm ekolojik hizmetleri sağlamak için gerekli olan biyolojik olarak verimli alanı vermektedir. Böylece ekolojik ayak izi her ülkede bulunan biyokapasiteyle yani biyolojik olarak verimli alanla karşılaştırılabilir.

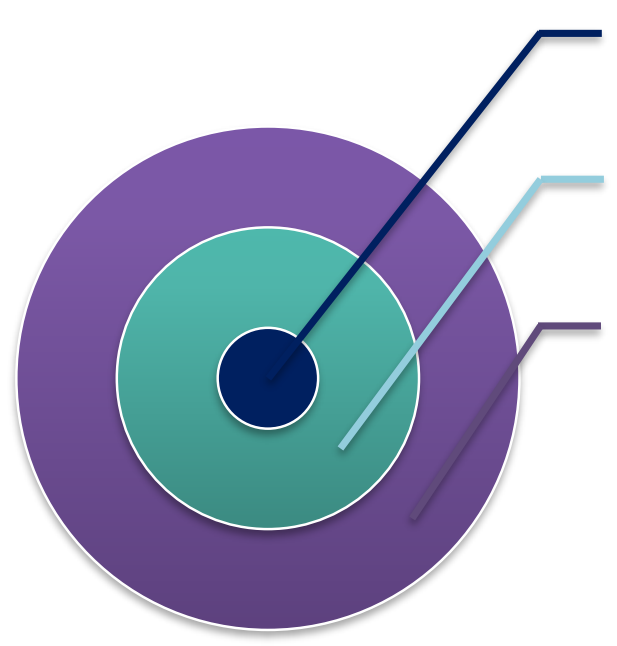

Tüketilen Kaynak ve

Üretilen Atığın Takibi

Kaynak ve Atık Akışlarının Gerekli Biyolojik Verimli Alana Çevrilmesi

Ekolojik Ayak İzi Hesaplamaları

Şekil 8: Ekolojik Ayak Izi hesaplamalarının baz alındığı faktörler

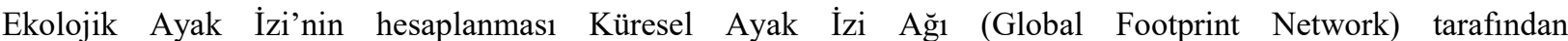
gerçekleştirilmektedir. Tablo 1'de Dünya genelinde hesaplanan toplam ekolojik ayak izi ve biyokapasite değerlerine göre ilk 10 ülkenin sıralaması verilmiştir. Tabloya göre Çin'in yüksek teknolojik gelişimi, artan nüfusu ve hesaplanan toplam biyokapasite miktarı ekolojik açıklığın yüksek olduğunu gözler önüne sermektedir. Bunun yanında Japonya'nın tüketim miktarının artışına paralel olarak artan ekolojik ayak izinin yanında ülkenin ekolojik kaynak miktarı olan toplam biyokapasite miktarının az olmasından dolayı ekolojik açıklık miktarı oldukça yüksektir. Hatta bu ekolojik açıklık değeri düşük ekolojik ayak izi ve biyokapasite değerine sahip Kore'den bile oldukça yüksektir.

Tablo 1: Toplam Ekolojik Ayak Izi Sıralamasındaki İk 10 Ülke (GFN 2019)

Ülke Adl Toplam Ekolojik Ayak İzi

(Küresel Hektar)

\begin{tabular}{r|c|c|}
\hline Çin & 5.200 .000 .000 & 1.370 .000 .000 \\
\hline Amerika Birleşik Devletleri & 2.610 .000 .000 & 1.170 .000 .000 \\
\hline Hindistan & 1.550 .000 .000 & 556.000 .000 \\
\hline Rusya & 743.000 .000 & 1.000 .000 .000 \\
\hline Brezilya & 584.000 .000 & 1.810 .000 .000 \\
\hline Japonya & 574.000 .000 & 74.300 .000 \\
\hline Endonezya & 441.000 .000 & 334.000 .000 \\
\hline Meksika & 397.000 .000 & 133.000 .000 \\
\hline Kore & 332.000 .000 & 150.000 .000 \\
\hline
\end{tabular}

Tablo 2'deyse Dünya genelinde hesaplanan kişi başına düşen ekolojik ayak izi ve biyokapasite değerlerine göre ilk 10 ülkenin sıralaması verilmiştir. Bu sıralamaya göre ekonomik bakımdan oldukça yüksek düzeyde olan ve düşük nüfusa sahip olan Katar'ın kişi başına düşen ekolojik ayak izi oldukça yüksek iken, yüzey alanının oldukça az ve biyolojik üretken arazisinin az olmasından kaynaklı kişi başına düşen ekolojik açıklık miktarı oldukça yüksektir. Bunun yanında yüksek biyokapasiteye sahip olan Kanada ve Moğolistan'daki kişi başına düşen düşük ekolojik ayak izi miktarları, bu ülkelerdeki ekolojik açıklığın az olduğunu hatta olmadığını göstermektedir. Bu durum Kanada ve Moğolistan'ın sürdürülebilir bir çevre politikası izlediğini göstermektedir. 
Tablo 2: Kişi Başına Düşen Ekolojik Ayak Izi Sıralamasındaki IIlk 10 Ülke (GFN 2019)

\section{$\ddot{U l k e} A d$}

\begin{tabular}{r} 
Kato \\
Lüksembur \\
\hline Birleşik Arap Emirliğ \\
Bahrey \\
Kuveyt \\
\hline Trinidat ve Tobag \\
\hline Kanadika Birleşik Devletle \\
Moğolistan \\
Bermuda Ada
\end{tabular}

Kişi Başına Düş̧en

Ekolojik Ayak İzi

(Küresel Hektar)
Kişi Başına Düş̧en

Biyokapasite

(Küresel Hektar)

\begin{tabular}{|c|c|c|}
\hline$r$ & 14.4 & 1.0 \\
\hline$g$ & 12.9 & 1.2 \\
\hline$n$ & 8.9 & 0.6 \\
\hline$t$ & 8.6 & 0.5 \\
\hline$o$ & 8.6 & 0.6 \\
\hline$i$ & 8.4 & 1.6 \\
\hline$a$ & 8.1 & 3.6 \\
\hline i & 7.7 & 15.1 \\
\hline
\end{tabular}

\subsection{Ekolojik Ayak İzi'ne Tarihsel Bakış}

İnsanoğlunun doğaya olan bağımlılığının biyofiziksel olarak değerlendirme süreci çok eskilere dayanmaktadır. Bunun en güzel örneklerinden bir tanesi sürdürülebilir kaynak kullanımıyla ilgili ele alınan 1664'de John Evelyn'in yayınladığı "Sylva, ya da Orman Ağaçları Söylemi ve Majestelerinin Hakimiyetinde Kereste Yayılımı (Sylva; or, A Discourse of Forest-Trees, and The Propagation of Timber in His Majesties Dominions)" adlı İngilizce bilimsel kitaptır. Bu kitap sonrasında Kuzey Amerika'nın, George Perkins Marsh'in 1864'de en çok okunan çalışması “İnsan ve Doğa" insan ihtiyaçlarını sağlayan doğanın sınırlı kapasitesine ilişkin farkındalığı arttırmada etkili olmuştur. İnsan ve doğa arasındaki ilişkinin sürdürülebilirliğinin sağlanılmasında önemli olan resmi ekolojik muhasebe fikriyse 1758 tarihinde, François Quesnay "Ekonomik Tablo"kitabını yayınladığında toprak verimliliği ve varlık yaratımı arasındaki ilişkiyi yakalamasıyla oluşmuştur (Wackernagel ve Monfreda 2004). Yayınlanan bu kitaplar sonrasında sessiz bir cennet olan doğada üretimin arttırılması amacıyla kullanılan pestisitlerin doğal kaynaklar üzerinde etkili olduğunu gösteren Sessiz Bahar kitabı ile insanların doğayı sömürdüğüne vurguda bulunulmuştur. Çevre ve ekonominin bütünleşmesinde etkin olan yayınlar tarihsel sıralaması Şekil 9'da gösterilmektedir.

1664 John EVELYN
1758 François QUESNAY

"Ekonomik Tablo"
1864

George PERKINS

"Insan ve Doğa"

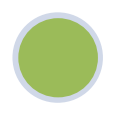

1962

\section{Rachel CARSON}

\footnotetext{
"Slylva, ya da

Orman Ağaçlart Söylemi ve

Majestelerinin

Hakimiyetinde

Kereste

Yayılımı"
}

Şekil 9: Çevre ve ekonominin bütünleşmesinde etkin olan yayınlar

1960'larda ve 1970'lerde yapılan, özellikle Borgstrom analizi "Ghost Acreage (Hayalet Alan)”, William Catton'un "Phantom Planets (Hayalet Gezegen)", Odum'un Enerji Akışlarıyla Enerji Analiz Sistemlerinin incelenmesi, Forrester'ın Dünya Kaynak Dinamiklerinin Modellemesi'ndeki ilerlemeleri, Holdren ve Ehrlich'in IPAT (Human Impact on The Environment $(\mathrm{I})=$ Population $(\mathrm{P}) \times$ Affluence $(\mathrm{A}) \times$ Technology $(\mathrm{T}))$ formülü, ya da, Uluslararas Biyolojik Programın ruhuyla, Whittaker'in Dünya Ekosistemlerinin Net Birincil Üretimi'ni hesaplamas1 gibi girişimlerle pek çok entelektüel yeni çalışmanın temelleri atılmıştır (Wackernagel vd. 1999). Ekolojik Ayak İzi'nin uygulanmasından daha önce, bir çok teorik ekolojist, insan faaliyetlerinin ekolojik süreçlerinin bütünlüğü üzerindeki etkisini karakterize etmek için Şekil 10'da belirtilen nicel analiz yöntemlerinin geliştirilmesinde önemli ilerleme kaydetmiş̧ir (Giampietro ve Saltelli 2014).

1965 yılında Borgstrom, ulusların "görünmez" bir taşınma kapasitesine (yani, gezegenin başka bir yerinde bulunan) dayandığını ima ederek kaynakların (özellikle gıdaya atıfta bulunur) kullanımındaki görülen fazlalığını açıklamışır. "Mevcut alanlara" karşı (ülkenin sınırları dâhilindeki çiftlik ve mera alanları), görünmez taşıma kapasitesi alanları "hayalet alan" olarak adlandırmışıı, "ticaret alanı" (net gıda ithalatından kaynaklanan kesir) ve "balık alanı" (denizden elde edilen yiyecekler) olarak iki bileşene ayırılmıştır (Herva vd. 2011). 
$\mathrm{Bu}$ hesaplamayla ülkelerin şu andaki beslenme düzeylerinin karşılanması için gerekli olan tarımsal alan ile gelecekte oluşacak ihtiyaçları karşılaması için gerekecek tarımsal arazilerin tanımlanması yapılmıştır.

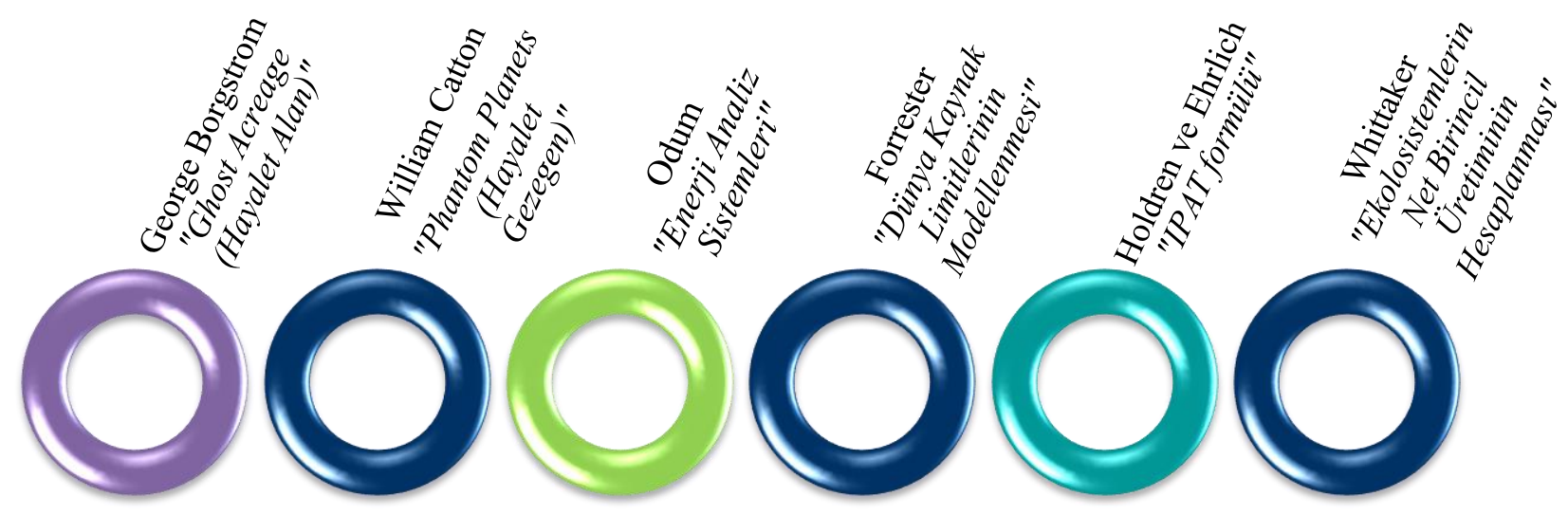

Şekil 10: Ekolojik değişimlerin incelenmesinde kullanılan yöntemler

Bu konsept 1980'lerde Hindistan'da kullanılmıştır ve 1992'de Rio De Janerio'da UNCED'e liderlik eden Jim MacNeill ve meslektaşları tarafından genişletilmiştir. Yakın zamanlarda Wackernagel ve Rees hayalet arazi fikrini ortaya atıp bu konu hakkında tartışmışlardır. Bu ekolojik kavram, şu anda var olmayan ekosistemlerin ekolojik verimliliğini günümüzde nasıl tükettiğimizi ifade etmektedir (McManus ve Haughton 2006). 90'lı yılların gelmesiyle birlikte ekosistemlerin arazi bazlı incelenmesi amacıyla yeni değerlendirme metotlarına olan ihtiyaç artmıştır. Bu amaçla çevresel açıklık ve çevresel ayak iz gibi kavramları gündeme gelmeye başlamıştır. Çevresel açık kavramı ilk olarak 1982'de Horst Sieber tarafından tanıtılmış, 1990'lı yılların başlarında J.B. Opschoor tarafından geliştirilebilmiştir (Herva vd. 2011). Çevresel alan kavramı, 1990'lı yılların başında Hans Opschoor tarafından insan tüketimi için mevcut olan çeşitli kaynakların sınırlandırılmasıyla oluşturulmuştur. Kaynak kıtlığının gelecek yüzyılda ekonomik kalkınma için ciddi bir engel teşkil edebileceğinden kaçınmak için yeterli rezervin uzun vadeli kullanılabilirliğini güvence altına almak için gerekli kaynak kullanımındaki azalmaları hesaplamayı amaçlamıştır.

Ekolojik Ayak İzi kavramı, 1990'ların başlarında British Columbia Üniversitesi'nde Mathis Wackernagel ve William Rees tarafindan oluşturulmuştur (Wackernagel 1991; Rees 1992; Wackernagel 1994; Rees 1996; Wackernagel ve Rees 1998). Taşıma kapasitesini çevreleyen güncel tartışmalara yanıt veren (Meadows vd. 1972; Ehrlich 1982; Tiezzi 1984; Brown ve Kane 1994), ekolojik ayak izi hesaplaması, biyolojik kaynakların insan tüketimini ve atık ekosistem alanı açısından atık üretimini temsil edecek şekilde tasarlanmıştır. Sadece biyoüretim alanına ve halihazırda üretilen ve atılan kaynaklara odaklanıldığında, bu yöntem biyosfer üzerindeki insan talebinin ve biyosferin bu spesifik talepleri karşılama yeteneğinin odaklanmış bir tarihsel değerlendirmesini sağlamıştır (Atlas 2010). Hem Ekolojik Ayak İzi, hem talep ölçüsü hem de bu talebi karşılayacak kapasite ölçüsü olan biyolojik kapasitenin sonuçları aynı birimde ifade edilmektedir. Bu birim, belirli bir yıldaki dünya ortalamasının biyolojik üretkenlik ile birlikte hektar olarak biyolojik olarak verimli bir kara veya deniz alanını temsil etmektedir (Goldfinger vd. 2014). Ekolojik Ayak İzi hesaplamaları tam konum olarak belirlenip hesaplanamaz bunun yerine elde olan veriler kullanılarak bulunan verilere atama yapılarak bir hesaplama gerçekleştirilmektedir. Yani hesaplama sistemi toplulukların oluşturduğu atıkları ve doğada oluşturdukları baskıların basitleştirilmesine dayanmaktadır (Wackernagel vd. 1997).

Ekolojik Ayak İzi farklı şekillerde 100'den fazla şehir veya bölgede uygulanarak değerlendirilmiştir. Örneğin, Amerika Birleşik Devletleri'nde, Sonoma County, California'nın "Time to Lighten Up" başlıklı Footprint projesi, ilçedeki her şehre, Uluslararası Yerel Çevre İnisiyatifleri Konseyi'nin İklim Koruyucu Girişimi'ne katılma konusunda ilham kaynağı olmuştur (Atlas 2010). Ulusal Ayak İzi hesaplanması için en çok kullanılan metodoloji Global Footprint Network'ün (Küresel Ayak İzi Ağı) 75'in üzerinde ortak kuruluş tarafindan geliştirilen ve sürdürülen Ulusal Ayak İzi hesaplamalarıdır. Bu referans hesapları 150'den fazla ülkeyi kapsamakta ve 1961'den 2003'e kadar uzanmaktadır. Bu hesapların kalitesini ve doğruluğunu geliştirme süreci, Global Footprint Network'ün Ulusal Hesaplar İnceleme Komitesi tarafından, Footprint araştırmacılarının küresel topluluğundan (Network 2007) talep edilen araştırma katkılarıyla denetlenmektedir (Kitzes vd. 2009).

$\mathrm{Bu}$ hesaplama metodolojilerinin yanı sıra son Tablo 3'de belirtildiği gibi 10-15 yıl içerisinde heyecan verici yeni gelişmeler yaşanmış ve ekosistem dengesinin değerlendirilmesi amacıyla yeni çalışmalar yapılmıştır. 
Tablo 3: Kullanılan uygulamalar (Wackernagel vd. 1999)

\begin{tabular}{l} 
Yaşam Döngüsü Değerlendirmeleri \\
Enerji tabanlı yaşam tarzı değerlendirmeleri \\
Opshoor'un fikirlerine geri dönen ve Dünya'nın dostları tarafından geliştirilen çevresel uzam \\
hesaplamaları \\
Net birincil üretimin insan ödeneği \\
Bölgesel ve endüstriyel metabolizmaların belgelenmesi \\
\hline Hizmet Birimi Başına Kütle Yoğunluğu (MIPS) gibi kütle yoğunluğu ölçümleri \\
Sürdürülebilir Süreç Endeksi (SPI) gibi insan süreçlerinin göstergeleri \\
\hline Sistematik sosyo-ekolojik göstergeler \\
\hline Ekosistem hizmetlerinin değerlendirilmesi \\
\hline Kaynak muhasebesi girdi-çıktı modelleri \\
\hline Arazi kullanımındaki gelişmeleri ve ekolojik potansiyelleri analiz eden bilgisayar tabanlı \\
mekansal modeller
\end{tabular}

"PoleStar" gibi bilgisayar tabanlı senaryo modelleri

$\mathrm{Bu}$ analiz yöntemlerinin her biri kütle sabitliği ilkesi ve termodinamiğin ilk iki kanunu üzerine inşa edildiği için, sonuçları sadece benzer değil, çoğu durumda da uyumludur. Başvurular ve temsilleri farklılık göstersede, amaçları aynıdır ve bunlar; etkisinin azaltılmasını motive etmek ve uygulamak için doğanın insani kullanımını ölçmektir. Yapılan yeni çalışmalarda, bu hesaplama metotları için veri elde etmek ve elde edilen verilerin doğruluğunu tam anlamıyla bilmek mümkün olmadığından sonuçların doğruluğundan şüphe duyulmaktadır. Bu nedenle ekolojik baskıyı ifade etmek amacıyla Coğrafi Bilgi Sistemleri (CBS) gibi uydu tabanlı veri elde etme sistemleri kullanılmaya başlanmaktadır (Chang ve Xiong 2005).

\subsection{Ayak İzi Ailesi}

Çevresel ayak izleri sürdürülebilirliğin en önemli belirteci olan çevresel sorunların değerlendirilmesi amacıyla oluşturulmuşlardır. Çevresel ayak izleri tüm ekosistemin sınırları ile ilişkili olup, ekosistemin eşik değerlerindeki değişimler dikkate alınmazsa, doğal çevrenin biyo-fiziksel süreçlerinde tolere edilemeyen değişimleri meydana getirebilmektedir (Hoekstra ve Wiedmann 2014). Bu yüzden ekolojik sistemin değerlendirilmesinde çevresel ayak izleri vazgeçilmez bir indikatördür. Son zamanlarda sürdürülebilirlik kavramının değerlendirilmesi amacıyla farklı disiplinlerin bir araya gelmesiyle Ayak İzi Ailesi kavramı oluşturulmuştur. Ayak İzleri, çevre üzerindeki insan baskısının ve bu baskıdan (arazi kullanım değişimleri, arazi kaybı, nehir akışı azaltılması, su kirliliği, küresel iklim değişimleri) ve bileşke etkilerden (örneğin; biyoçeşitlilik azalması, insan sağlı̆̆ı ve ekonomi) kaynaklanan çevresel etkileri basit bir şekilde anlatan indikatörlerdir (Hoekstra ve Wiedmann 2014).

$\mathrm{Bu}$ indikatörlerin her biri ayrı ayrı hesaplanıp değerlendirildiklerinde farklı sonuçlar verebilmektedir. Bu yüzden her bir ayak izi bütünleşik bir sistem kullanılarak değerlendirmelidir. Şekil 12'de belirtildiği gibi ayak izi ailesi kendi içerisinde Çevresel Ayak İzleri, Sosyal Ayak İzleri, Ekonomik Ayak İzleri, Kombine Çevre, Sosyal ve/veya Ekolojik Ayak İzleri ve Komposit Ayak İzleri olarak altı gruba ayrılmaktadır. Sosyal Ayak İzileri; İnsan Hakları Ayak İzi (İKG), Yolsuzluk Ayak İzi (COF), Yoksulluk Ayak İzi (POF), İş Ayak İzi (JF), Çalışma Ortamı Ayak İzi (WEF) ve Sağlık Ayak İzi (HLF) gibi insanların yaşam şartlarını değerlendirilerek sürdürülebilirliğin bir ölçüsü olan huzurun ve sosyal imkanların sağlanması amacıyla kullanılmaktadırlar. Ekonomik Ayak İzleri; Finansal Ayak İzi (FF) ve Ekonomik Ayak İzi (ECF) olarak iki başlığa ayrılmaktadır. Ekonomik Ayak İzi sürdürebilirliğin önündeki bir başka engel olan ekonomik adaletsizliğin değerlendirilmesini sağlamaktadır. Çevresel Ayak İzleri; Karbon Ayak İzi (CF), Su Ayak İzi (WF), Enerji Ayak İzi (EF), Emisyon Ayak İzi (EMF), Nitrojen Ayak İzi (NF), Arazi Ayak İzi (LF), Biyoçeşitlik Ayak İzi (BF) olarak ayrılmaktadır.

Çevresel Ayak İzi’nden biri olan Karbon Ayak İzi, genellikle bir işlem ya da ürünün tüm yaşam döngüsü aracıllğıyla atılmış $\mathrm{CO}_{2}$ ve diğer Sera Gazlarının (GHG) miktarının temsildir. Karbon Ayak İzi, küresel 1sınma ve iklim değişikliğine katkıda bulunan Sera Gazlarının miktarını temsil eden Küresel Isınma Potansiyeli (GWP) gibi indikatörleri kullanılarak ölçülmektedir. 
İnsan popülasyonun artmasıyla birlikte artan tüketim miktarı ve buna bağlı artan üretim miktarı ile oluşan doğrudan veya dolaylı sera gazı emisyonları Karbon Ayak İzi’ni ifade etmektedir. Üretim süreci içerisinde oluşturulan emisyonların değerlendirilebilmesi için Emisyon Ayak İzi ifadesi kullanılmaktadır.

Emisyon Ayak İzi, hava ( $\mathrm{SO}_{2}$, partikül madde, $\left.\mathrm{CO}, \mathrm{CO}_{2}\right)$, su (Kimyasal Oksijen İhtiyacı (KOİ), nitrojen ve fosfor), ve toprağa verilen ürün ya da hizmet kaynaklı emisyonların miktarını temsil eder. Emisyon Ayak İzleri birim-alan temelli hesaplanmaktadır. Emisyon ve Karbon Ayak İzi'nin yanı sıra insanlığın devamlılığında önemli bir parametre olan suyun tüketim miktarının sürdürülebilir kullanımını sağlamak için Su Ayak İzi ifadesi kullanılmaktadır.

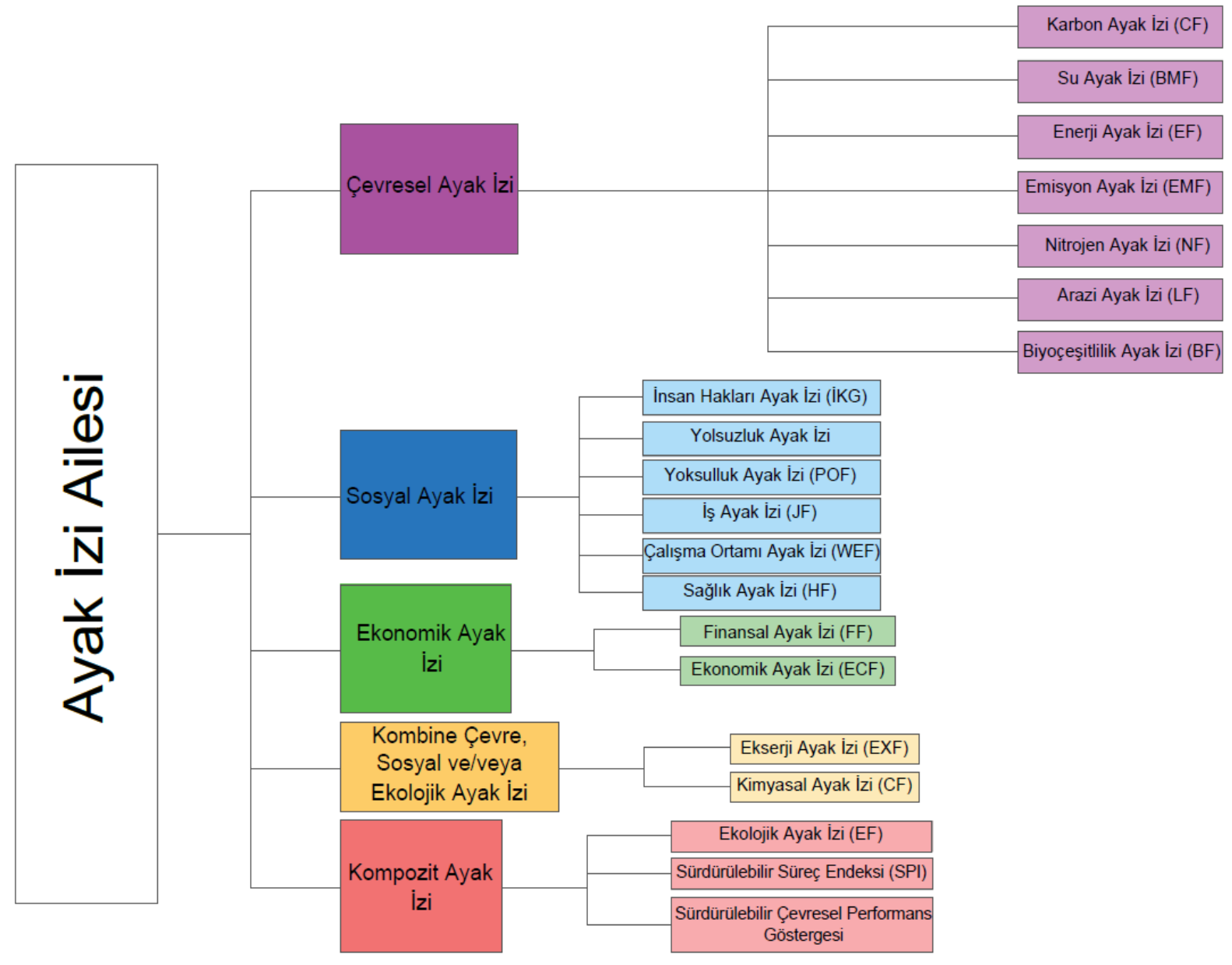

Şekil 12. Ayak Izi ailesi ve birbirleriyle olan ilişkileri

Su Ayak İzi belirli bir bölge içindeki bireyler ve topluluklar tarafindan tüketilen tüm ürünlerin ve hizmetlerin içeriği kümülatif sanal su olarak ifade edilmektedir. Bir ürünün gerçek su içeriği, çoğu durumda, sanal su içeriğinden çok daha az olabilmektedir. Su Ayak İzi böylece bu gömülü enerjiyi basit bir yolla tanımlamış olmaktadır "ş̧ekillendirilen su" olarak adlandırılabilir (Fang vd. 2014). Su Ayak İzi ifadesi Şekil 13'de gösterildiği üzere üç ana bileşen olan mavi, yeşil ve gri su ayak izlerinden meydana gelmektedir. Mavi Ayak İzi (BWF), Dünya'daki tatlı su kaynaklarının bireyler ve toplumlar tarafından su kullanımın etkilerinin ölçümüdür. Mavi Su Ayak İzi (BWF), su tüketimini (su miktarı), kaynak stresini (su stresi indeksi) ve kalitesini (su etkisi endeksi) dikkate alır ve suyu eşdeğer hacimsel birimler formunda ifade etmektedir (Čuček vd. 2012). Yeşil Su Ayak İzi, özellikle mahsul üretimi için uygun yeşil su (yağmur suyu) hacmidir. Gri Su Ayak İzi, tatlı su kirliliği derecesinin bir indikatörüdür ve mevcut ortam su kalitesi standartlarında bulunan kirlilik yükünü asimile etmek için gerekli tatlı su hacmi olarak ifade edilmektedir (Hoekstra ve Mekonnen 2012).

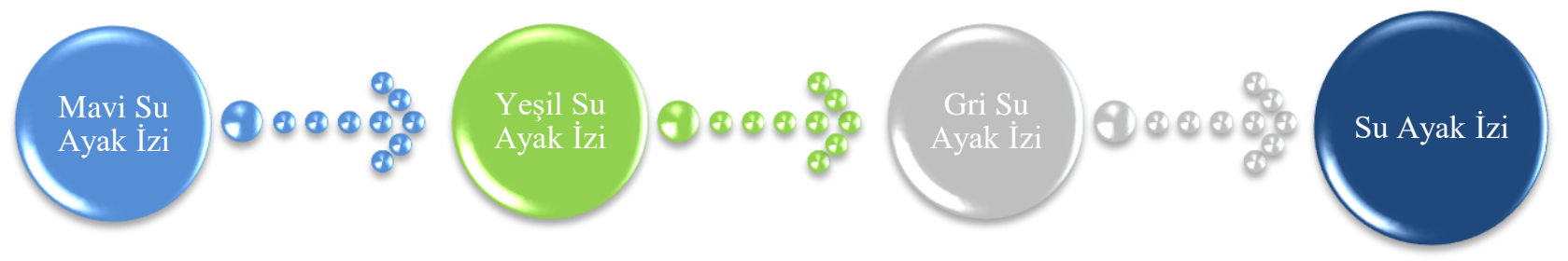

Şekil 13: Su Ayak Izi'nin bileşenleri 
Dünyada yaşamsal bir element olan azot insanların tarımsal aktiviteleri ve fosil yakıt tüketimine bağlı olarak artmaktadır. İnsanların çevredeki reaktif azotu $\left(\mathrm{N}_{\mathrm{r}}\right)$ kullanımlarının insan üzerinde çok derin yararlı ve zararlı etkileri vardır. Yararlı etkileri gıda üretimi ve endüstriyel uygulamalardan kaynaklanmaktadır. Zararlı etkiler, gıda üretimde kullanılmış olan ve fosil yakıt yanması sırasındaki $\mathrm{N}_{\mathrm{r}}$ 'nin tümünün, insanların ve ekosistemlerin her ikisini de olumsuz yönde etkileyen çevre değişiminin bir basamağı olan çevre kaybından dolayı oluşmaktadır (Leach vd. 2012). Tüketim ve üretim evresi sırasında oluşturan reaktif azotun $\left(\mathrm{N}_{\mathrm{r}}\right)$ yönetiminin sağlanabilmesi için Nitrojen Ayak İzi ifadesi kullanılmaktadır. Nitrojen Ayak İzi, insan aktivitelerinin bir sonucu olarak açığa çıkan reaktif nitrojen $\left(\mathrm{N}_{\mathrm{r}^{-}} \mathrm{N}_{2}\right.$ dişındaki nitrojen türlerinin tümü) miktarının bir ölçümüdür, toplam $\mathrm{N}_{\mathrm{r}}$ birimlerinden ifade edilmektedir (Čuček vd. 2012). İnsanların bu üretim ve tüketimleri sağlayabilmeleri için kullandıkları ortamlar yani arazilerin artan nüfusa bağlı olan değişimlerinin takibinin sağlanarak sürdürülebilir bir arazi kullanımının oluşturulması gereklidir. Bu amaçla Arazi Ayak İzi ifadesi kullanılmaktadır ve Arazi Ayak İzi Şekil 14'de belirtildiği gibi kullanım alanlarına göre kategorize edilmektedir. Arazi Ayak İzi, Orman Ayak İzi (FLF, tüketilen orman ürünlerinin üretimi için gereken ormanlık alan (Nature 2006)); Tarımsal Arazi Ayak İzi (ALF, tarımsal arazinin biyomass yetiştirmek için kullandığı alan (Kissinger ve Gottlieb 2010)); Gelișen Arazi Ayak İzi (BLF, arazide insan alt yapısının kapladığı alan (Chambers 2004)); Otlak Alan Ayak İzi (GLF, hayvancılık için kullanılan alan) ve Ekim Alanı Ayak İzi (CLF, bir popülasyon tarafından tüketilen mahsullerin üretilmesi için gereken arazi alanı (Van Rooyen 2005)) gibi alt-ayak izlerini içermektedir (Čuček vd. 2012).

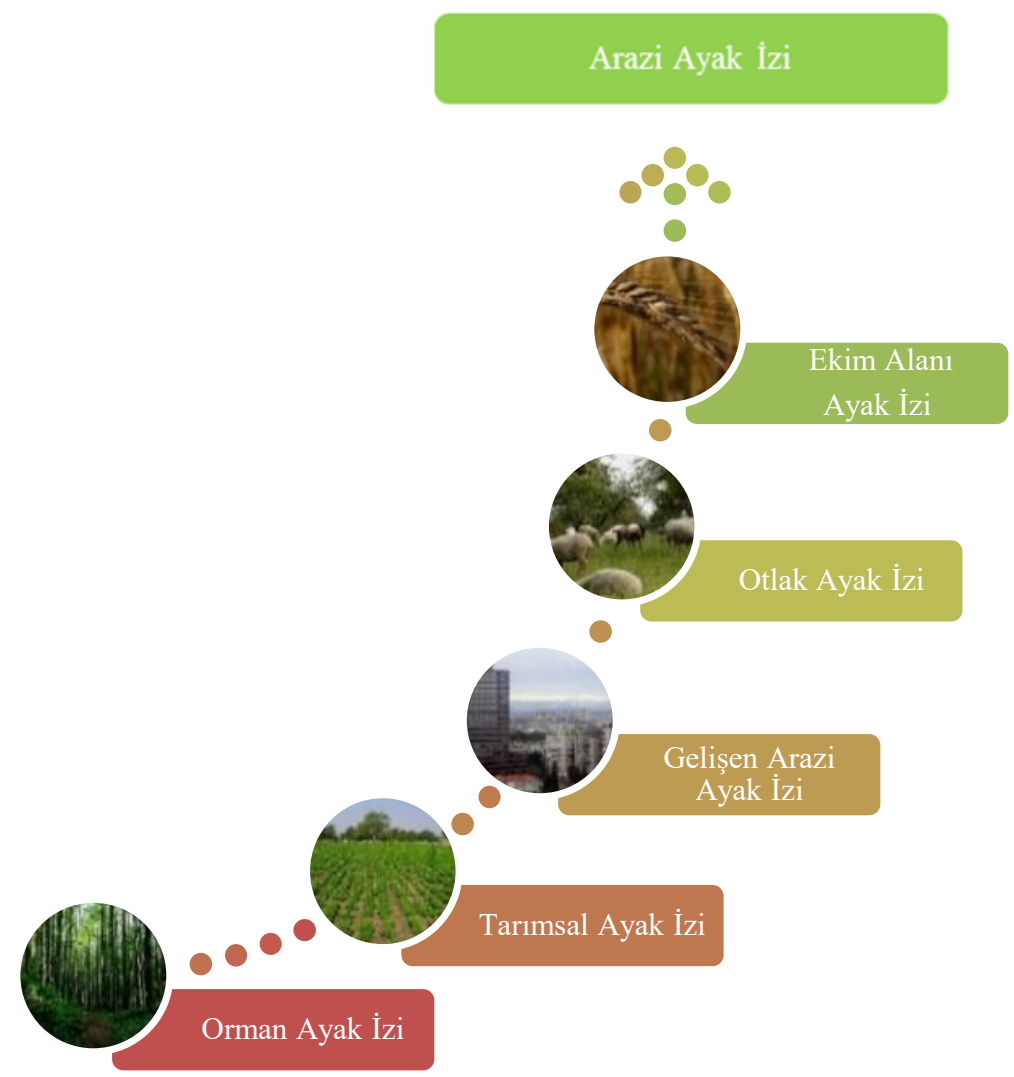

Şekil 14: Arazi Ayak Izi

Tüketimin artışıyla birlikte çevreye oluşturulan baskının yanı sıra doğadaki ekosistemlere ve canlı türlerine olan baskıda gün geçtikçe artmaktadır. Doğal kaynakların bu şekilde tahsis edilmesi insanların ihtiyaçlarından meydana gelmektedir. Bu durum, habitatların bozulması ya da azalmasına, kirliliğe, iklim değişikliğine, biyotik değişim ya da aşırı kullanıma sebebiyet verdiğinden çoğunlukla biyoçeşitlilik için olumsuzdur (Marques vd. 2017). Bu olumsuzlukları ortadan kaldırılarak canlı türlerinin koruma altına alınabilmesi için Biyoçeşitlilik Ayak İzi ifadesi kullanılmaktadır. Biyoçeşitlilik Ayak İzi; biyoçeşitlilik kaybını, alan değişimi sonucu, arazi kullanımı değişimlerini, biyolojik kaynakların sürdürülemez kullanımını, sucul ekosistem kaynaklarının aşırı sömürülmesini ve egzotik türlerin istilasını ölçmektedir (Čuček vd. 2012). Kombine Çevre, Sosyal ve/veya Ekolojik Ayak İzleri; Ekserji Ayak İzi (EXF) ve Kimyasal Ayak İzi (CHF) olarak iki alt kavrama ayrılmaktadır. Bu ayak izleri enerji ve kimyasal gibi doğal varlıkların kullanılma, tüketilme ve tüketilirken form değiştirmesi sonucunda çevrede oluşturacağı etkilerin ifadesinde kullanılmaktadır. Bir diğer ayak izi ise Kompozit Ayak İzi kavramıdır. Bu kavramdan iki ya da daha fazla bireysel gösterge ya da alt göstergenin bir araya getirilir, böylece karmaşık bilgilerin bir arada durması sağlanarak tek bir indeksle değerlendirilmesi gerçekleştirilir. 
Şekil 15'de belirtildiği gibi Ekserji Ayak İzi ifadesi; Ekolojik Ayak İzi (EF), Sürdürülebilir Süreç Endeksi (SPI) ve Sürdürülebilir Çevresel Performans Göstergesi (SEPI) ifadelerinden oluşmaktadır.
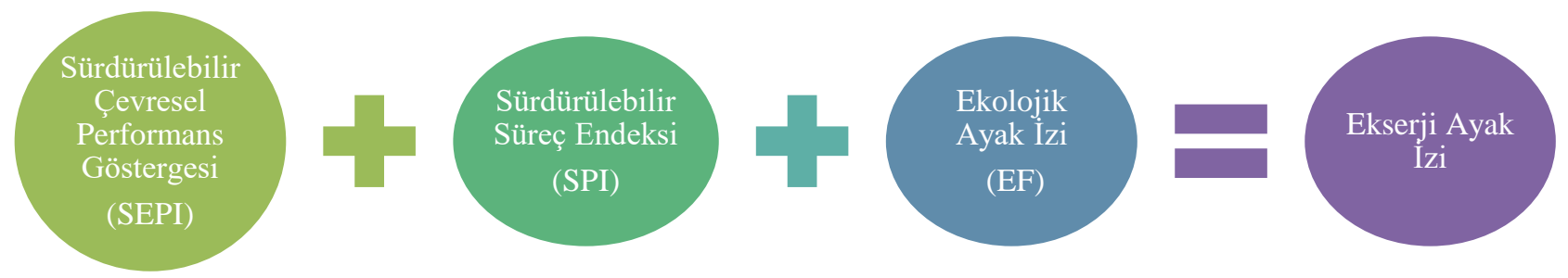

Şekil 15: Ekserji ayak izi ifadesinin taban kavramları

\section{Sonuç}

Bütün canlılar doğdukları andan itibaren aynı doğal ekosistemi paylaşırlar ve bu ekosistem içerisinde yaşamsal enerjilerini sağlamak amacıyla doğal kaynakları tüketirler. Ancak insanoğlu doğanın sahibi olduğu düşüncesiyle dünyadaki bütün ekolojik kaynakların üzerine hükümdarlığını kurarak onları amansızca tüketip harap etmektedir. İnsanoğlunun bu amaçsızca her şeye sahip olma isteğiyle daha çok ekonomik ve ekolojik kaynak tüketme davranışı, düzenle işleyen ekosistemleri büyük bir baskı altına sokmaktadır. Ekosistemler üzerine oluşturulan her bir baskı şu anda bulunduğumuz dünyanın kaynak oluşturma kapasitesini ve tüketim sonucunda oluşan atıkların eliminasyon edilme potansiyellerini git gide düşürmektedir. Ekosistem servislerinde oluşan baskılar, gelecek nesillerin yaşamlarını nasıl devam ettirebilecekleri sorusunu akıllara getirmektedir. Bu düşünce doğrultusunda ortaya çıkan sürdürülebilirlik kavramıla birlikte ekonomik büyümenin sadece maddi bir kazanç değil bir taraftan da ekolojik bir kayıp olduğuna dair farkındalıklar artmaya başlamıştır. Birbirlerinden tanımsal ve yapısal olarak farklı olan ekoloji ve ekonomi bu karşılıklı fayda mekanizması 1şığında, ekolojik değerlerin ekonomik anlamı ve ekonomik değerleri ekolojik değer olarak ifade eden "ekolojik ekonomi” kavramı oluşturulmuştur. Oluşturulan bu ekolojik ekonomi kavramı dünya üzerindeki ekolojik değerlerin nicel ifadesinde kullanılan ilk basamağı meydana getirmiştir. Ancak ekolojik ekonomi kavramı ister istemez ekonomi ekseninde kalarak sadece ekonomik bir değerlendirmenin yapılmasını sağlamaktadır. Avrupa Birliği ekonomik büyümenin gerçekleştirilmesi ve bu büyümenin yanında kaynakların kontrollü biçimde kullanılmasını hedeflemektedir. Ancak Avrupa Birliği'nin 2000 yılında Lizbonda gerçekleştirdiği Avrupa Konseyi'nde kabul ettiği Lizbon Gündemi rekabet gücünü ve istihdamı arttırmayı amaçladığından eleştirilere maruz kalmıştır. Bu nedenle 2001 yılında Göteburg'da gerçekleştirilen Avrupa Konseyi'nde Lizbon Gündemi içerisinde çevre konusunun eksik olduğu belirtilerek Sürdürülebilir Kalkınma Stratejisi (SKS) kabul edilmiştir. Bu amaç doğrultusunda Avrupa Birliği kaynakların verimli kullanılması için Ekolojik Ayak İzi (Ecological Footprint-EF), Çevre Ağırlıklı Malzeme Tüketimi (Environmentally Weighted Material Consumption-EMC), Net Birincil İnsan Ödeneği (Human Appropriation of Net Primary Production-HANPP) ve Arazi ve Ekosistem Hesapları (Land and Ecosystem Accounts-LEAC) kullanılmaktadır (Best vd. 2008).

Ekonomik bakış açısının yanı sıra ekolojik kaynakların tüketimlerinin doğal denge üzerindeki etkilerinin de değerlendirilmesine ihtiyaç duyulmaktadır. Çevresel felaketlerin artması ve doğal kaynakların git gide azalması ekolojik kaynakların tüketim miktarlarının belirlenerek sayısallaştırmasının önünü açmıştır. Ayak izi kavramı kaynak tüketim ve üretimlerinin çeşitli boyutlarda incelenmesini sağlayarak bütüncül bir değerlendirmeye imkân vermektedir. Ekolojik Ayak İzi ifadesi biyolojik olarak üretken altı alan üzerinden değerlendirilmektedir ve bu değerlendirme insan tüketimlerinin yönetilmesi sürecinde büyük bir avantaj sağlamaktadır. Ekolojik Ayak İzi’nin değerlendirilmesi sürecinde önemli olan bir diğer ifade olan insanlar için kaynak oluşturan biyokapasite miktarı dünya üzerindeki kaynakların yönetilmesinde ve ekolojik açıklıkların belirlenmesinde büyük bir önem taşımaktadır. Ekolojik açıklık ifadesi tüketimi temsil eden ekolojik ayak izi ifadesi ile üretimi ifade eden biyokapasite miktarı arasındaki farkı temsil etmektedir. Sürdürülebilir bir geleceğin sağlanılabilmesi için ekolojik açıklık ifadesinin azaltılması yani ekolojik ayak izi miktarının azaltılması veya biyokapasite miktarının arttırılması gerekmektedir. Biyokapasite miktarının kısa bir zaman periyodu içerisinde arttırılması oldukça düşük bir ihtimal olduğundan Ekolojik Ayak İzi ifadesinin azaltılması büyük önem arz etmektedir. Ekolojik Ayak İzi ifadesi alan bazında hektar (ha) veya kilometrekare $\left(\mathrm{km}^{2}\right)$ ifadeleri kullanılarak değerlendirilmektedir ve bu değerlendirmeler dışında dünya üzerindeki toplam biyokapasite miktarını temsil eden küresel hektar (kha) cinsinden ifade edilmektedir. Bu durum ülkeler arasında değişiklik gösteren Ekolojik Ayak İzi değerlerinin karşılaştırılmasını ve değerlendirilmesini sağlamaktadır. Ülkemizin Ekolojik Ayak İzi değeri Küresel Ayak İzi Ağı'nın 2016 yılı hesaplamalarına göre 3.4 küresel hektardır. Bunun yanında ekolojik kaynakların sürdürülebilirliğinde büyük bir öneme sahip olan biyokapasite değeriyse Küresel Ayak İzi Ağı'nın 2016 yılı hesaplamalarına göre 1.5 küresel hektardır. Ekolojik Ayak İzi ve biyokapasite arasında fark (-) 1.9 küresel hektardır ve bu durum ekolojik kaynaklarda bir açıklık olduğunu ifade etmektedir. Bu durumun önüne geçilebilmesi için Ekolojik Ayak İzi değerlerinin azaltılması amacıyla kaynakların doğru kullanılması üretimin sürdürülebilir olarak gerçekleştirilmesi ve insanlığın sürdürülebilir bir yaşam tarzına geçmesi gerekmektedir. 


\section{Kaynaklar}

Atlas E.F., (2010), Global Footprint network, http://www.footprintnetwork.org/en/ındex.php/gfn/page/ecological_footprint_atlas_ 2010, [Erişim 28 Temmuz 2011].

Best A., Blobel D., Cavalieri S., Giljum S., Hammer M., Lutter S., Lewis K., (2008), Potential of The ecological footprint for monitoring environmental impacts from natural resource use, Report to The European Commission, DG Environment.

Brown L., Kane H., (1994), Full house: Reassessing the earth's population carrying capacity, W.W. Norton, New York, 261 ss.

Carson R., (1962), Silent spring, Fortieth Anniversary Edition, Houghton Mifflin, Boston, 400s.

Chambers N., (2004), Scotland's footprint: a resource flow and ecological footprint analysis of Scotland, Best Food Forward Limited.

Chang B., Xiong L., (2005), Ecological Footprint analysis based on RS and GIS in arid land, Journal Of Geographical Sciences, $15(1), 44-52$.

Čuček L., Klemeš J.J., Kravanja Z., (2012), A review of footprint analysis tools for monitoring impacts on sustainability, Journal Of Cleaner Production, 34, 9-20.

Ehrlich P.R., (1982), Human carrying capacity, extinctions, and nature reserves, Bioscience, 32(5), 331-333.

Fang K., Heijungs R., De Snoo G.R., (2014), Theoretical exploration for the combination of the ecological, energy, carbon, and water footprints: overview of a footprint family, Ecological Indicators, 36, 508-518.

Giampietro M., Saltelli A., (2014), Footprints to nowhere, Ecological Indicators, 46, 610-621.

GFN, (2019), Ecological Footprint explorer, https://data.footprintnetwork.org/\#/, [Erişim 28 Ocak 2020].

Goldfinger S., Wackernagel M., Galli A., Lazarus E., Lin D., (2014), Footprint facts and fallacies: a response to giampietro and saltelli (2014) "footprints to nowhere", Ecological Indicators, 46, 622-632.

Hammond G.P., (2006), 'People, planet and prosperity': the determinants of humanity's environmental footprint, Natural Resources Forum, 27-36.

Herva M., Franco A., Carrasco E.F., Roca E., (2011), Review of corporate environmental indicators, Journal Of Cleaner Production, 19(15), 1687-1699.

Hoekstra A.Y., Mekonnen M.M., (2012), The Water footprint of humanity, Proceedings of The National Academy of Sciences, 109(9), 3232-3237.

Hoekstra A.Y., Wiedmann T.O., (2014), Humanity's Unsustainable environmental footprint, science, 344(6188), 1114-1117.

Kissinger M., Gottlieb D., (2010), Place oriented ecological footprint analysis-the case of Israel's Grain supply, Ecological Economics, 69(8), 1639-1645.

Kitzes J., Galli A., Bagliani M., Barrett J., Dige G., Ede S., Erb K., Giljum S., Haberl H., Hails C., Jolia-Ferrier L., Jungwirth S., Lenzen M., Lewis K., Loh J., Marchettini N., Messinger H., Milne K., Moles R., Monfreda C., Moran D., Nakano K., Pyhälä A., Rees W., Simmons C., Wackernagel M., Wada Y., Walsh C., Wiedmann T., (2009), A research agenda for improving national ecological footprint accounts, Ecological Economics, 68(7), 1991-2007.

Kıvılcım İ., (2013), 2020’ye doğru Kyoto-Tipi iklim değişikliği müzakereleri, avrupa birliği'nin yeterliliği ve Türkiye'nin konumu, İktisadi Kalkınma Vakfi Yayınları, İstanbul.

Koroneos C.J., Rokos D., (2012), Sustainable and integrated development-a critical analysis, Sustainability, 4(1), 141-153.

Leach A.M., Galloway J.N., Bleeker A., Erisman J.W., Kohn R., Kitzes J., (2012), A nitrogen footprint model to help consumers understand their role in nitrogen losses to the environment, Environmental Development, 1(1), 40-66.

Marques A., Verones F., Kok M.T.J., Huijbregts M.A.J., Pereira H.M., (2017), How to quantify biodiversity footprints of consumption? a review of multi-regional input-output analysis and life cycle assessment, Current Opinion In Environmental Sustainability, 29, 75-81.

McManus P., Haughton G., (2006), Planning with ecological footprints: a sympathetic critique of theory and practice, Environment And Urbanization, 18(1), 113-127.

Meadows D.H., Meadows D.L., Randers J., Behrens W.W., (1972), The Limits to growth, New York, 102, 27.

Moffatt I., (2000), Ecological footprints and sustainable development, Ecological Economics, 32(3), 359-362.

Nature W.W.F.F., (2006), Living planet report, The Fund, https://wwf.ru/en/resources/publications/booklets/living-planet-report2006/, [Erişim 08 Ekim 2019].

Network G.F., (2007), Ecological footprint: overview, Global Footprint Network, https://www.footprintnetwork.org/ourwork/ecological-footprint/, [Erişim 01 Ağustos 2007].

Parıltı H., (2019), Küresel çevre rejimleri ve ülkelerin uluslararası ticaret politikaları, Haliç Üniversitesi Sosyal Bilimleri Dergisi, 2(2), 323-370.

Paul B.D., (2008), A history of the concept of sustainable development: literature review, The Annals of The University of Oradea, 17(2), 581.

Penna A.N., (2010), The human footprint: a global environmental history, Second edition, John Wiley-Blackwell, ss. 1-13, ISBN 978-1-118-91246-1.

Rees W.E., (1992), Ecological footprints and appropriated carrying capacity: what urban economics leaves out, Environment And Urbanization, 4(2), 121-130.

Rees W.E., (1995), Cumulative environmental assessment and global change, Environmental Impact Assessment Review, 15(4), 295-309.

Rees W.E., (1996), Revisiting Carrying capacity: area-based indicators of sustainability, Population and Environment, 17(3), 195215.

Rees W.E., Wackernagel M., (1996), Urban ecological footprints: why cities cannot be sustainable-and why they are a key to sustainability, Environmental Impact Assessment Review, 16(4-6), 223-248.

Robertson M., (2014), Sustainability Principles and practice, Routledge, New York, 1-18, ISBN 978-0-415-84018-7.

Røpke I., (2005), Trends in the development of ecological economics from the late 1980s to the early 2000s, Ecological Economics, 55(2), 262-290. 
Rojas-Fernández A.G., Aguilar-Santelises L., Millán M.C., Aguilar-Santelises M., García-Del Valle A., (2017), Teaching Chemistry with sustainability, multidisciplinary journal for education, Social And Technological Sciences, 4(1), 102-121.

San-Francisco A., Sopelana N., Fernandez J.M., Otegi J.R., ve Minguez R., (2020), Analysis about the incorporation of remanufacturing concept into life cycle assessment theorie, Journal of Remanufacturing, 1-13.

Tiezzi E., (1984), Tempi storici, tempi biologici, Garzanti, Milano,(English Translation: Tiezzi, E., 2003), WIT Press, Southampton, UK.

Toprak D., (2006), Sürdürülebilir kalkinma çevresinde çevre politikalari ve mali araçlar, Süleyman Demirel Üniversitesi Sosyal Bilimler Enstitüsü Dergisi, 2, 146-169.

Turan E., Güner E.D., (2017), Türkiye'de çevresel etki değerlendirme mevzuatının değişimi, Doğal Afetler ve Çevre Dergisi, 3(1), $39-47$.

URL-1, (2019), On birinci kalkınma planı (2019-2023), T.C. Cumhuriyeti Cumhurbaşkanlığı Strateji ve Bütçe Başkanlığ1, http://www.sbb.gov.tr/wp-content/uploads/2019/07/OnbirinciKalkinmaPlani.pdf, [Erişim 28 Ocak 2020].

Van Rooyen C.J., (2005), Synergy of agriculture, community development, and eco-tourism agri-tourism farm complex, Doktora Tezi, University of Pretoria, South Africa.

Wackernagel M., (1991), Using 'appropriated carrying capacity'as an indicator: measuring the sustainability of a community, The UBC Task Force On Healthy And Sustainable Communities, UBC School of Community and Regional Planning, Vancouver.

Wackernagel M., (1994), Ecological footprint and appropriated carrying capacity: a tool for planning toward sustainability, Doktora Tezi, University of British Columbia.

Wackernagel M., Onisto L., Linares A.C., Falfãn I.S.L., Garcia J.M., Guerrero A.I.S., (1997), Ecological Footprints of Nations, Universidad Anahuac de Xalapa, Centro de Estudios para la Sustentabilidad, 1-9.

Wackernagel M., Rees W., (1998), Our Ecological Footprint: Reducing Human Impact on the Earth, New Society Publishers, Philadelphia, 7-85.

Wackernagel M., Lewan L. ve Hansson C. B., (1999), Evaluating the use of natural capital with the ecological footprint: applications in sweden and subregions, Ambio, 604-612.

Wackernagel M., Onisto L., Bello P., Callejas Linares A., Susana López Falfán I., Méndez García J., Isabel Suárez Guerrero A., Guadalupe Suárez Guerrero M., (1999), National natural capital accounting with the ecological footprint concept, Ecological Economics, 29(3), 375-390.

Wackernagel M., Monfreda C., (2004), Ecological footprints and energy, Encyclopedia Of Energy, 2(1), 1-11.

WCED S.W.S., (1987), World commission on environment and development, Our Common Future, 17, 1-91. 